\title{
Secondary organic aerosol from atmospheric photooxidation of indole
}

\author{
Julia Montoya-Aguilera ${ }^{1}$, Jeremy R. Horne ${ }^{2}$, Mallory L. Hinks ${ }^{1}$, Lauren T. Fleming ${ }^{1}$, Véronique Perraud ${ }^{1}$, Peng Lin ${ }^{3}$, \\ Alexander Laskin ${ }^{3}$, Julia Laskin $^{3}$, Donald Dabdub ${ }^{2}$, and Sergey A. Nizkorodov ${ }^{1}$ \\ ${ }^{1}$ Department of Chemistry, University of California, Irvine, CA 92697, USA \\ ${ }^{2}$ Department of Mechanical and Aerospace Engineering, University of California, Irvine, CA 92697, USA \\ ${ }^{3}$ Department of Chemistry, Purdue University, West Lafayette, IN 47907, USA
}

Correspondence to: Sergey A. Nizkorodov (nizkorod@uci.edu)

Received: 22 March 2017 - Discussion started: 28 March 2017

Revised: 20 August 2017 - Accepted: 23 August 2017 - Published: 28 September 2017

\begin{abstract}
Indole is a heterocyclic compound emitted by various plant species under stressed conditions or during flowering events. The formation, optical properties, and chemical composition of secondary organic aerosol (SOA) formed by low- $\mathrm{NO}_{x}$ photooxidation of indole were investigated. The SOA yield $(1.3 \pm 0.3)$ was estimated from measuring the particle mass concentration with a scanning mobility particle sizer (SMPS) and correcting it for wall loss effects. The high value of the SOA mass yield suggests that most oxidized indole products eventually end up in the particle phase. The SOA particles were collected on filters and analysed offline with UV-vis spectrophotometry to measure the mass absorption coefficient (MAC) of the bulk sample. The samples were visibly brown and had MAC values of $\sim 2 \mathrm{~m}^{2} \mathrm{~g}^{-1}$ at $\lambda=300 \mathrm{~nm}$ and $\sim 0.5 \mathrm{~m}^{2} \mathrm{~g}^{-1}$ at $\lambda=400 \mathrm{~nm}$, comparable to strongly absorbing brown carbon emitted from biomass burning. The chemical composition of SOA was examined with several mass spectrometry methods. Direct analysis in real-time mass spectrometry (DART-MS) and nanospray desorption electrospray high-resolution mass spectrometry (nano-DESI-HRMS) were both used to provide information about the overall distribution of SOA compounds. High-performance liquid chromatography, coupled to photodiode array spectrophotometry and high-resolution mass spectrometry (HPLC-PDA-HRMS), was used to identify chromophoric compounds that are responsible for the brown colour of SOA. Indole derivatives, such as tryptanthrin, indirubin, indigo dye, and indoxyl red, were found to contribute significantly to the visible absorption spectrum of indole SOA. The potential effect of indole SOA on air qual-
\end{abstract}

ity was explored with an airshed model, which found elevated concentrations of indole SOA during the afternoon hours contributing considerably to the total organic aerosol under selected scenarios. Because of its high MAC values, indole SOA can contribute to decreased visibility and poor air quality.

\section{Introduction}

Atmospheric particulate matter (PM) absorbs and scatters solar radiation and is responsible for diminished visibility in urban areas and for global changes in climate. A key component of PM is secondary organic aerosol (SOA). While air quality model prediction capabilities have improved in recent years, disagreements between SOA predictions and measurements remain (Couvidat et al., 2013; Heald et al., 2005; Hodzic et al., 2010; Jiang et al., 2012; Volkamer et al., 2006). Discrepancies may result from incorrect or incomplete parameterizations of mechanisms for known SOA precursors, as well as from unaccounted precursors of SOA. Atmospheric researchers have investigated in detail the SOA generated from oxidation of basic anthropogenic and biogenic volatile organic compounds (VOCs), such as isoprene, monoterpenes, saturated hydrocarbons, and aromatic hydrocarbons. Much less is known about SOA from nitrogencontaining VOCs, even though such VOCs are also common in the atmospheric environment and can potentially provide significant additional pathways for SOA formation. For ex- 
ample, photooxidation of amines could serve as a possible SOA source (Price et al., 2014; Silva et al., 2008).

Heterocyclic nitrogen-containing aromatic compounds based on pyrrole, pyridine, imidazole, indole, diazines, purines, etc., have been detected in biomass burning emissions (Laskin et al., 2009). Such compounds can also be emitted by vegetation; for example, indole is produced by wide variety of plants (Cardoza et al., 2003; De Boer et al., 2004; Gols et al., 1999; McCall et al., 1993; Turlings et al., 1990; Zhuang et al., 2012). Indole is emitted in response to physical or herbivore-induced stress (Erb et al., 2015; Frey et al., 2004; Misztal et al., 2015; Niinemets et al., 2013; Schmelz et al., 2003; Turlings et al., 2004) and during flowering events (Gentner et al., 2014). Once emitted, indole performs critical roles in plant ecology, for example in attracting pollinators (Zito et al., 2015). For decades, indole and its derivatives (Fig. 1) have been utilized in agriculture, dyes, perfumes, and pharmaceutical applications. One of the better-known derivatives of indole is indigo dye (also known as indigotin), which is used to give jeans their characteristic deep blue colour.

Studies of maize plants under stress revealed that indole acts as an aerial priming agent, released before terpenoids (Erb et al., 2015; Schmelz et al., 2003). For example, Schmelz et al. (2003) examined insect induced volatile emissions in Zea Mays seedlings and demonstrated direct positive relationships between jasmonic acid levels and both sesquiterpene and indole volatile emissions. Additionally, they showed that indole can reach maximal emission levels during nocturnal herbivory and concluded that indole could function as an early morning signal for parasitoids and predators searching for insect hosts and prey. Niinemets et al. (2013) found evidence that quantitative relationships exist between the severity of biotic stress and induced volatile emissions, in addition to the previously demonstrated dose-response relationships for abiotic stresses. Erb et al. (2015) showed that herbivore induced indole emissions in maize plants precede the release of mono-, homo-, and sesquiterpenes, supporting the conclusion that indole is involved in the airborne priming of terpenoids. Different plant stress mechanisms typically elicit release of the same ubiquitous stress volatiles, such as indole, and more stress-specific mono- and sesquiterpene blends (Erb et al., 2015; Gentner et al., 2014; Niinemets et al., 2013; Schmelz et al., 2003).

Emissions of indole have also been well correlated with monoterpene emissions during flowering events (Gentner et al., 2014). Ambient measurements conducted by Gentner et al. (2014) showed that both daytime and nighttime concentrations of indole at their field site in California's San Joaquin Valley were similar to or greater than the dominant monoterpene $\beta$-myrcene. The authors stressed the need for future laboratory and modelling studies on the SOA formation potential of indole and other novel compounds identified in their study. A later study by Misztal et al. (2015) used a combination of laboratory experiments, ambient measurements, and emissions modelling to show that plants emit a wide variety of benzenoid compounds (including indole) to the atmosphere at substantial rates and that current VOC inventories underestimate biogenic benzenoid emissions. They concluded that emissions of benzenoids from plants are likely to increase in the future due to changes in the global environment and stressed that atmospheric chemistry models should account for this potentially important precursor of SOA.

An additional potential source of indole is animal husbandry, but the emission rate of indole from this source remains uncertain. In concentrated animal feeding operations (CAFOs), indole is primarily emitted from animal waste (Yuan et al., 2017) and can contribute significantly to the malodours in cattle feed yards and swine facilities (Feilberg et al., 2010; Wright et al., 2005). While Yuan et al. (2017) indicated that indole is emitted from dairy operations, beef feed yards, sheep feed yards, and chicken feed yards, the emission rate of indole from these sources was not quantified. Other studies have quantified the emission rate of indole but only for pig facilities (Feilberg et al., 2010; Hobbs et al., 2004). The United States Department of Agriculture (USDA) 2012 census agriculture atlas maps show no hogs or pigs in the model domain used in this study. Furthermore, Hobbs et al. (2004) showed only trace emissions of indole from cattle slurry and did not detect indole from laying hen manure. Thus, emissions of indole from animal husbandry are not included in this study but should be considered when modelling areas with active animal husbandry facilities.

Despite the importance of indole in the atmospheric environment, only a few studies exist on the mechanism of its photooxidation. Gas-phase oxidation of indole by $\mathrm{OH}, \mathrm{O}_{3}$, and $\mathrm{NO}_{3}$ was previously studied by Atkinson et al. (1995). They found that indole reacts with $\mathrm{OH}$ and $\mathrm{NO}_{3}$ at collision-limited rates, with rate constants of $1.5 \times$ $10^{-10}$ and $1.3 \times 10^{-10} \mathrm{~cm}^{3} \mathrm{molec}^{-1} \mathrm{~s}^{-1}$, respectively. The rate for the reaction of indole with $\mathrm{O}_{3}$ (rate constant of $5 \times 10^{-17} \mathrm{~cm}^{3} \mathrm{molec}^{-1} \mathrm{~s}^{-1}$ ) and the rate of direct photolysis were found to be too low to compete with the $\mathrm{OH}$ and $\mathrm{NO}_{3}$ reactions. Atkinson et al. (1995) observed 2formylformanilide (Fig. 1) as the major primary product of oxidation of indole by both $\mathrm{O}_{3}$ and $\mathrm{OH}$. Oxidation of indole was also studied by Iddon et al. (1971) in $\gamma$-irradiated aqueous solutions, where oxidation by $\mathrm{OH}$ was the dominant reaction mechanism. The reaction produced 3-oxindole, indoxyl red, indirubin, and indigo dye and eventually resulted in a trimer of 3-oxindole and two indole molecules as the major products.

Until now, the formation of SOA from indole has not been investigated. One of the motivations for investigating indole SOA is that it may possess unusual optical properties. Many of the indole-derived products are brightly coloured and have distinctive absorption bands in visible spectrum. If these products are formed during atmospheric oxidation of indole and partition into aerosol particles, they could contribute to the pool of organic light-absorbing species. Such 


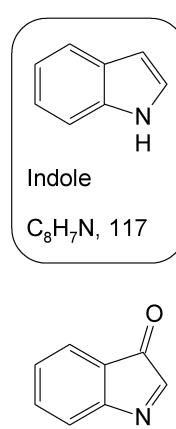

3-oxyindole

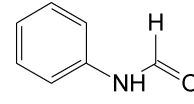

2-formylformanilide

$\mathrm{C}_{7} \mathrm{H}_{7} \mathrm{NO}, 121$<smiles>O=C1Nc2ccccc2C1=O</smiles>

Isatin<smiles>Oc1c[nH]c2ccccc12</smiles>

Indoxyl

$\mathrm{C}_{8} \mathrm{H}_{7} \mathrm{NO}, 133$<smiles>Nc1ccccc1C(=O)O</smiles>

Anthranilic acid

$\mathrm{C}_{7} \mathrm{H}_{7} \mathrm{NO}_{2}, 137$<smiles>O=C1CNc2ccccc21</smiles>

3-oxindole

$\mathrm{C}_{8} \mathrm{H}_{7} \mathrm{NO}, 133$<smiles>O=c1[nH]c2ccccc2c(=O)o1</smiles>

Isatoic anhydride

$\mathrm{C}_{8} \mathrm{H}_{5} \mathrm{NO}_{3}, 163$<smiles>O=C1/C(=C2\Nc3ccccc3C2=O)Nc2ccccc21</smiles>

Indigo dye

$\mathrm{C}_{16} \mathrm{H}_{10} \mathrm{~N}_{2} \mathrm{O}_{2}, 262$<smiles>O=C1C(=C2C=Nc3ccccc32)Nc2ccccc21</smiles>

Indoxyl red

$\mathrm{C}_{16} \mathrm{H}_{10} \mathrm{~N}_{2} \mathrm{O}, 246$

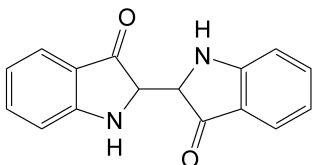

Dihydro indigo dye

$\mathrm{C}_{16} \mathrm{H}_{12} \mathrm{~N}_{2} \mathrm{O}_{2}, 264$

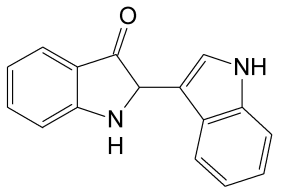

Dihydro indoxyl red

$\mathrm{C}_{16} \mathrm{H}_{12} \mathrm{~N}_{2} \mathrm{O}, 248$<smiles>O=C1Nc2ccccc2/C1=C1/Nc2ccccc2C1=O</smiles>

Indirubin

$\mathrm{C}_{16} \mathrm{H}_{10} \mathrm{~N}_{2} \mathrm{O}_{2}, 262$

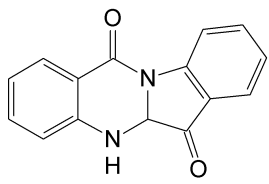

Tryptanthrin

$\mathrm{C}_{15} \mathrm{H}_{10} \mathrm{~N}_{2} \mathrm{O}_{2}, 250$

Figure 1. Chemical structures, common names, molecular formulas, and nominal molecular weights for indole and its oxidized derivatives discussed in this work.

organic compounds that absorb radiation strongly in the nearUV and visible spectral ranges are collectively known as "brown carbon" in the atmospheric literature (Andreae and Gelencser, 2006; Laskin et al., 2015).

In this work, we investigate the formation of indole SOA in a smog chamber and characterize its molecular composition and optical properties. We incorporate these results into an airshed model with detailed SOA chemistry to estimate the effect of indole on the total SOA and on the lightabsorbing components of SOA. We show that indole can measurably contribute to SOA loading even in urban environments, where anthropogenic emissions dominate over biogenic ones, such as the South Coast Air Basin of California (SoCAB). Furthermore, we show that indole SOA contains unique strongly absorbing compounds and can contribute to decreased visibility, especially under plant-stressed conditions or during flowering events.

\section{Experimental methods}

SOA was generated in a $5 \mathrm{~m}^{3}$ Teflon chamber under low relative humidity ( $\mathrm{RH}<2 \%$; Vaisala HMT333 probe). No inorganic seed aerosol was used because it would interfere with offline mass-spectrometric analysis of SOA. Hydrogen peroxide was introduced into the chamber by evaporation of a 30 weight percent solution of $\mathrm{H}_{2} \mathrm{O}_{2}$ in water (Fisher Scientific) into a flow of clean air to achieve an initial mixing ratio of 2 part per million by volume (ppmv). Indole (99\% purity, Sigma-Aldrich) was dissolved in methanol (LC-MS grade, 99.9\% purity, Honeywell) and was evaporated into the chamber to obtain an initial mixing ratio of 200 parts per billion by volume (ppbv), which is equivalent to $960 \mathrm{\mu g} \mathrm{m}^{-3}$. The injector and inlet lines were heated to $70^{\circ} \mathrm{C}$ to minimize losses on the surfaces. At room temperature, the reported vapour pressure of indole is $0.012 \mathrm{mmHg}$ (Das et al., 1993), which is equivalent to $\sim 16 \mathrm{ppmv}$. Therefore, most of the injected indole should have remained in the gas phase although some of it could remain adsorbed to the injection line and cham- 
ber wall surfaces, contributing to the variability in the SOA yield (see below). The content of the chamber was mixed with a fan for $10 \mathrm{~min}$ following the injection. After mixing was stopped, UV-B lamps were turned on to initiate the photooxidation. In some experiments, complete mixing was achieved only after the lamps were turned on as evidenced by the measured indole concentrations continuing to increase in the initial photooxidation period. Although mixing was not fast, it was faster than the timescale of the reaction, so it should not have affected the SOA mass yield calculations. Throughout the experiment, size and number concentration of particles were monitored with a scanning mobility particle sizer (SMPS; TSI 3936). A proton-transfer-reaction timeof-flight mass spectrometer (PTR-ToF-MS; Ionicon model 8000) monitored the decay of indole and the formation of volatile photooxidation products. The PTR-ToF-MS had a resolving power of $m / \Delta m \sim 5 \times 10^{3}$ and was operated with the following settings: drift tube temperature of $60^{\circ} \mathrm{C}$, drift tube voltage of $600 \mathrm{~V}$, field strength of $\sim 135 \mathrm{Td}$, and inlet flow of 0.2 SLM. When the SOA particles reached a peak concentration in the chamber, the UV irradiation was stopped, and the polydispersed particles were collected on one Teflon filter (47 mm diameter, Millipore FGLP04700) at $20 \mathrm{~L} \mathrm{~min}^{-1}$ for $3 \mathrm{~h}$. One filter was collected per each chamber run; therefore, each replicate sample was collected from a separate experiment run under the same conditions. The amount of the collected SOA material on each filter was estimated from SMPS data assuming $100 \%$ collection efficiency by the filters and SOA material density of $1.4 \mathrm{~g} \mathrm{~cm}^{-3}$. The density of indole SOA is unknown, but the adopted value of $1.4 \mathrm{~g} \mathrm{~cm}^{-3}$ is similar to the reported range of densities of $1.47-1.55 \mathrm{~g} \mathrm{~cm}^{-3}$ for SOA prepared from another bicyclic aromatic compound, naphthalene (Chan et al., 2009; Chen et al., 2016). In addition, densities of known indole oxidation products, for example isatin $\left(1.47 \mathrm{~g} \mathrm{~cm}^{-3}\right)$, anthranilic acid $\left(1.40 \mathrm{~g} \mathrm{~cm}^{-3}\right)$, indigo dye $\left(1.20 \mathrm{~g} \mathrm{~cm}^{-3}\right)$, isatoic anhydride $\left(1.52 \mathrm{~g} \mathrm{~cm}^{-3}\right)$, and 3-oxindole $\left(1.20 \mathrm{~g} \mathrm{~cm}^{-3}\right)$, range from 1.2 to $1.5 \mathrm{~g} \mathrm{~cm}^{-3}$, suggesting that $1.4 \mathrm{~g} \mathrm{~cm}^{-3}$ should be a reasonable guess for indole SOA.

The SOA yield was calculated from Eq. (1).

Yield $=\frac{\Delta \mathrm{SOA}}{\Delta \mathrm{VOC}}$

The increase in the mass concentration of particles, $\Delta \mathrm{SOA}$, was obtained from SMPS measurements and corrected for the particle wall loss as described in the Supplement. The change in the mass concentration of indole, $\triangle \mathrm{VOC}$, was equated to the initial indole concentration because PTR-ToFMS measurements suggested complete removal of indole during the photooxidation.

The filter with the collected sample was cut in half. The first half was used for UV-vis measurements. The sample was extracted by placing the filter half in a covered petri dish containing $3 \mathrm{~mL}$ of methanol (LC-MS grade, $99.9 \%$ purity, Honeywell) and shaken vigorously on a shaker for five minutes. Assuming a complete extraction of the SOA material, this would result in a mass concentration of 0.03$0.22 \mathrm{mg} \mathrm{mL}^{-1}$. The filter colour changed from brown to white, suggesting that most of the light-absorbing compounds were extracted. The assumption of a full extraction is supported by the solubility of $21 \mathrm{mg} \mathrm{mL}^{-1}$ reported for isatin in methanol (Baluja et al., 2013); methanol solubilities of other indole oxidation products are expected to be similarly high. The SOA methanol extract was then analysed by UV-vis spectrophotometry in a dual-beam spectrophotometer (Shimadzu UV-2450), with pure methanol used as reference. Wavelength-dependent mass absorption coefficient (MAC) was calculated for indole SOA from the base-10 absorbance, $A_{10}$, of an SOA extract, the path length, $b(\mathrm{~cm})$, and the solution mass concentration, $C_{\text {mass }}\left(\mathrm{g} \mathrm{cm}^{-3}\right)$ :

$\operatorname{MAC}(\lambda)=\frac{A_{10}^{\text {solution }}(\lambda) \times \ln (10)}{b \times C_{\text {mass }}}$.

The main uncertainty in the calculated MAC values comes from the uncertainty of the mass concentration, which arises from uncertainties in the SMPS measurement of aerosol mass concentration, filter collection efficiency, and solvent extraction efficiency. We estimate that MAC values should be accurate within a factor of 2 (Romonosky et al., 2015a).

The second half of the filter was used for direct analysis in real-time mass spectrometry (DART-MS) measurements. The filter half was extracted in the same way with $3 \mathrm{~mL}$ of acetonitrile (LC-MS grade, $99.9 \%$ purity, Honeywell). Assuming a complete extraction of the SOA material, the mass concentration of $0.03-0.22 \mathrm{mg} \mathrm{mL}^{-1}$ is much lower than the solubility of $19 \mathrm{mg} \mathrm{mL}^{-1}$ reported for isatin in acetonitrile (Liu et al., 2014). (We elected to use different solvents for UV-vis and DART-MS because methanol afforded measurements deeper in the UV region and acetonitrile gave cleaner background spectra in DART-MS. Based on visual inspection, the samples appeared to dissolve fully in both acetonitrile and methanol.) Aliquots from the acetonitrile SOA extracts were transferred onto a clean stainlesssteel mesh, dried in air, and manually inserted between the DART ion source and mass spectrometer inlet. The DARTMS consisted of a Xevo TQS quadrupole mass spectrometer (Waters) equipped with a commercial DART ion source (Ion-Sense, DART SVP with Vapur ${ }^{\circledR}$ Interface). It was operated with the following settings: $350 \mathrm{~V}$ grid electron voltage, $3.1 \mathrm{~L} \mathrm{~min}^{-1} \mathrm{He}$ gas flow, $350^{\circ} \mathrm{C} \mathrm{He}$ gas temperature, and $70^{\circ} \mathrm{C}$ source temperature. The samples were analysed with DART-MS in both positive and negative ion modes. Background spectra from the pure solvent were also collected and subtracted from the DART mass spectra.

Additional sample filters were analysed via nanospray desorption electrospray ionization high-resolution mass spectrometry (nano-DESI-HRMS) and high-performance liquid chromatography, coupled to photodiode array spectrophotometry and high-resolution mass spectrometry (HPLCPDA-HRMS). The former method provides a spectrum of 
the entire mixture without prior separation; it is useful for providing an overview of the types of compounds present in SOA. The latter method is suited for advanced detection of individual light-absorbing components in SOA (Lin et al., 2015a, b; Lin et al., 2016). Both methods employ an LTQOrbitrap mass spectrometer (Thermo Corp.) with a resolving power of $10^{5}$ at $m / z 400$, sufficient for unambiguous characterization of SOA constituents.

For the HPLC-PDA-HRMS measurements, one-quarter of the filter was extracted using $350 \mu \mathrm{L}$ acetonitrile $\left(\mathrm{CH}_{3} \mathrm{CN}\right.$, gradient grade, $\geq 99.9 \%$ purity) and the change in filter colour from brown to white suggested that most lightabsorbing compounds were extracted into the solution. Separation of the SOA extract was achieved with a Scherzo SMC18 column (Imtakt USA). The gradient elution protocol included a $3 \mathrm{~min}$ hold at $10 \%$ of $\mathrm{CH}_{3} \mathrm{CN}$, a 45 min linear gradient to $90 \% \mathrm{CH}_{3} \mathrm{CN}$, a 16 min hold at this level, a $1 \mathrm{~min}$ return to $10 \% \mathrm{CH}_{3} \mathrm{CN}$, and another hold until the total scan time of $90 \mathrm{~min}$. The column was maintained at $25^{\circ} \mathrm{C}$ and the sample injection volume was $8 \mu \mathrm{L}$. The UV-vis spectrum was measured using the PDA detector over the wavelength range of 250 to $700 \mathrm{~nm}$. The ESI settings were positive ionization mode, $+4.5 \mathrm{kV}$ spray potential, 35 units of sheath gas flow, 10 units of auxiliary gas flow, and 8 units of sweep gas flow.

The HRMS data analysis was performed by methods summarized by Romonosky et al. (2015b). Briefly, the mass spectra were clustered together, the $m / z$ axis was calibrated internally with respect to expected products of photooxidation, and the peaks were assigned to formulas $\mathrm{C}_{c} \mathrm{H}_{h} \mathrm{O}_{o} \mathrm{~N}_{n} \mathrm{Na}_{0-1}^{+}$ or $\mathrm{C}_{c} \mathrm{H}_{h} \mathrm{O}_{o} \mathrm{~N}_{n}^{-}$constrained by valence rules and elemental ratios $(c, h, o, n$ refer to the number of corresponding atoms in the ion). These were then converted to formulas of the corresponding neutral species, obtained by removing $\mathrm{Na}$ or $\mathrm{H}$ from the observed positive ion formulas or adding $\mathrm{H}$ to the negative ion formulas. The HPLC-PDA-HRMS analysis was done as described in Lin et al. (2015b, 2016).

\section{Modelling methods}

Air quality simulations were performed to complement laboratory experiments and to assess the formation of indole SOA in a coastal urban area. The University of California, Irvine, and California Institute of Technology (UCI-CIT) regional airshed model with a state-of-the-art chemical mechanism and aerosol modules was used in this study. The model domain utilized 4970 computational cells (five vertical layers with 994 cells per layer) with a $5 \mathrm{~km} \times 5 \mathrm{~km}$ horizontal grid size and encompassed the SoCAB, including the Pacific Ocean on the western side, heavily populated urban areas around Los Angeles, and locations with a high density of plant life such as the Angeles National Forest on the eastern side. The model included spatially and temporally resolved emissions and typical meteorological conditions for this region. The emission inventory used in this study was based on the 2012 Air Quality Management Plan (AQMP) provided by the South Coast Air Quality Management District (SCAQMD, 2013). Boundary and initial conditions were based on historical values. Simulations were performed for a 3-day summer episode. Two days of model spin-up time were used to reduce the influence of initial conditions and allow sufficient time for newly added emissions to drive changes in air quality. Results shown below are for the third day of the simulations.

The UCI-CIT model utilizes an expanded version of the Caltech atmospheric chemical mechanism (CACM; Dawson et al., 2016; Griffin et al., 2002a, b, 2005) and has been used in numerous other studies to simulate air quality in the SoCAB (Carreras-Sospedra et al., 2006; Carreras-Sospedra et al., 2010; Chang et al., 2010; Nguyen and Dabdub, 2002). The CACM includes a comprehensive treatment of SOA known as the Model to Predict the Multiphase Partitioning of Organics (MPMPO) (Griffin et al., 2003, 2005). MPMPO is a fully coupled aqueous-organic equilibrium-partitioningbased model and is used to calculate gas-particle conversion of secondary organic species. The SIMPOL.1 groupcontribution method of Pankow and Asher (2008) is used to calculate vapour pressures of SOA species for use in MPMPO. Activity in both the aqueous and organic phases is determined using the UNIFAC model of Hansen et al. (1991). Henry's law constants are calculated according to the group contribution method of Suzuki et al. (1992). Several studies have used the UCI-CIT model to investigate SOA formation, dynamics, reactivity, and partitioning phase preference in the SoCAB (Carreras-Sospedra et al., 2005; Chang et al., 2010; Cohan et al., 2013; Dawson et al., 2016; Griffin et al., 2002b; Vutukuru et al., 2006). For a more detailed description of recent model developments incorporated into the UCI-CIT model and its SOA modules, the reader is referred to Dawson et al. (2016).

For the present study, the chemical mechanism was modified from the base case version to include species and processes shown in Fig. 2. Two new gas-phase species were added: indole and one representative oxidation product, indigo dye. Because of the high mass yield of indole SOA, with most of the products ending up in the particle phase, any reasonable indole oxidation product with a low vapour pressure would be suitable. We elected to use indigo dye $\left(\mathrm{C}_{16} \mathrm{H}_{10} \mathrm{O}_{2} \mathrm{~N}_{2}\right)$ because it is a very common derivative of indole and because its formula was reasonably close to the average formula of SOA compounds determined from nano-DESI $\left(\mathrm{C}_{15} \mathrm{H}_{11} \mathrm{O}_{3} \mathrm{~N}_{2}\right)$. One new gas-phase reaction was added, which forms gas-phase indigo dye via oxidation of gas-phase indole by hydroxyl radical. Lastly, indigo dye was also added to the model as a new SOA species. Gas-phase indigo dye was assumed to partition into the aerosol phase based on its calculated vapour pressure and Henry's law constant. After the modifications described here, the model contained a total of 202 gas-phase species, 607 gas-phase reactions, and 18 SOA species. Each SOA species was sorted 


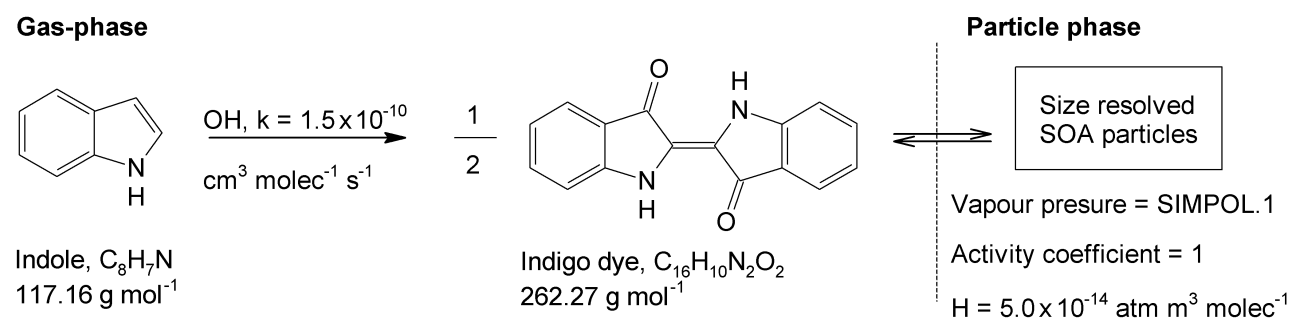

Figure 2. Summary of modifications made to the UCI-CIT model chemical mechanism and aerosol modules. In the simulation that included oxidation by $\mathrm{NO}_{3}$ an additional similar reaction was added with the indole $+\mathrm{NO}_{3}$ rate constant of $1.3 \times 10^{-10} \mathrm{~cm}^{3} \mathrm{molec}^{-1} \mathrm{~s}^{-1}$.

into eight distinct size bins based on particle diameter, up to a maximum of $10 \mu \mathrm{m}$. The activity coefficient of indigo dye was assumed to be 1 .

Because gas-phase indole was not included in the base case emissions inventory, its emission rate was estimated based on available literature data. As discussed in the introduction section, emissions of indole have been shown to be well correlated to emissions of monoterpenes in a variety of plant species (Erb et al., 2015; Gentner et al., 2014; Niinemets et al., 2013). However, most existing data were obtained from controlled laboratory experiments and emissions of indole at the regional scale are not well constrained. In this work, emissions of gas-phase indole were added to the base case emissions inventory by using a ratio to "BIOL", an existing gas-phase species in the emission inventory. BIOL is representative of lumped biogenic monoterpenes and contains spatially and temporally resolved emissions in the base case inventory. Therefore, the spatiotemporal distribution of indole emissions follows that of BIOL, with the magnitude of the emissions set to a given percentage of BIOL emissions. Please note that no emissions of indole derived from agriculture and animal husbandry activities were added in the model because these sources remain uncertain. In addition, no direct emissions of gas-phase indigo dye were added to the model. Because of the uncertainty and episodic nature of gas-phase indole emissions, simulations were performed with a range of possible emission factors to determine the sensitivity of indole SOA formation to gas-phase indole emissions.

Five scenarios were considered for model calculations. The first scenario had zero emissions of gas-phase indole. This scenario will be referred to as the "base case" and serve as the reference scenario to which the other scenarios are compared to determine changes in air quality. The second, third, and fourth scenarios had emissions of gas-phase indole set to 5,10 , and $25 \%$ of BIOL emissions, referred herein as "low", "medium", and "high" emissions, respectively. When averaged over the entire simulation domain, the corresponding average emission factors for indole were $0.25,0.51$, and $1.27 \mu \mathrm{g} \mathrm{m}^{-2} \mathrm{~h}^{-1}$, respectively. A comparable emission factor of $0.6 \mu \mathrm{g} \mathrm{m}^{-2} \mathrm{~h}^{-1}$ for indole was used in a previous study of Misztal et al. (2015), in which indole emissions under average stress conditions were incorporated in the MEGAN 2.1 biogenic VOC emissions model to estimate total global emissions. Therefore, the medium emission scenario considered in this study should be representative of the emissions of indole under average stress conditions, while the high emission scenario is more likely to represent episodic emission events such as those during springtime flowering or herbivore infestation.

The focus of this modelling work was to study the formation of SOA from the photooxidation of indole by $\mathrm{OH}$, in order to complement the experimental data reported in this work. While the SOA formation from oxidation of indole by $\mathrm{NO}_{3}$ was not experimentally studied, the reaction of indole with $\mathrm{NO}_{3}$ is fast and may provide an additional source of indole SOA. The fifth and final scenario explored the potential impact of including an additional oxidation pathway for gas-phase indole via reaction with $\mathrm{NO}_{3}$. This scenario corresponds to the high emission scenario with one new gasphase reaction included in the model in addition to those described previously. For this new reaction, it is assumed that gas-phase indole reacts with $\mathrm{NO}_{3}$ to produce indigo dye, the same representative oxidation product assumed for the reaction of gas-phase indole with hydroxyl radical. A rate constant of $1.3 \times 10^{-10} \mathrm{~cm}^{3}$ molec $^{-1} \mathrm{~s}^{-1}$ is used following Atkinson et al. (1995). No other changes were made to the model or its inputs in this scenario.

\section{Results and discussion}

\subsection{Properties of indole SOA}

Figure 3 illustrates the time dependence of mass concentrations of indole and particulate matter in a typical chamber experiment. According to PTR-ToF-MS measurements, indole decayed with a half-life of approximately $60 \mathrm{~min}$, which translates into an average $\mathrm{OH}$ concentration in the chamber of $1.4 \times 10^{6} \mathrm{molec}^{-3}$, similar to ambient levels (Fig. S2.1 in the Supplement). The PTR-ToF mass spectrum of indole before photooxidation (Fig. S2.2) was dominated by the protonated indole at $m / z 118.067$ (the $m / z$ values cited in the text correspond to the measured $\mathrm{m} / \mathrm{z}$ values; the corresponding exact $m / z$ values are listed in Table S2 in the Supplement). After photooxidation, a few other prominent peaks 


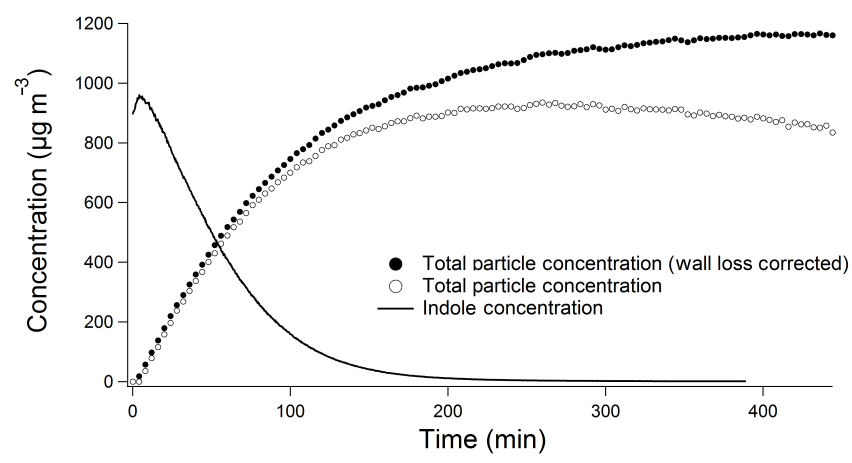

Figure 3. The mass concentration of indole (solid trace), the mass concentration of particles (open circles), and the wall-loss-corrected mass concentration of particles (solid circles) over time. Indole was not yet fully mixed in the chamber by the time photooxidation started at $t=0$, resulting in an apparent initial rise in the measured indole concentration.

appeared. Figures S2.3 and S2.4 show the time-dependence profiles of several peaks of interest detected by PTR-ToF-MS during the photooxidation of indole, and Table S2 contains their proposed assignments. Peaks at $m / z$ 120.072, 131.062, and 132.050 (Fig. S2.4) appeared simultaneously with indole injection, suggesting that the indole sample contained small amounts $(<2 \%)$ of indoline, diazanaphthalene, and 3-oxyindole impurities, respectively, which may have contributed to SOA formation. From the ions that first appeared and then were consumed during photooxidation (Fig. S2.3), the one at $m / z 122.061$ had the largest peak abundance. It corresponds to protonated 2-formylformanilide $[\mathrm{M}+\mathrm{H}]^{+}$ion (Fig. 1), a major gas-phase product of indole oxidation by $\mathrm{OH}$ (Atkinson et al., 1995). Another significant product was detected at $m / z 148.041$ and was tentatively assigned to the $[\mathrm{M}+\mathrm{H}]^{+}$ion from isatin (Fig. 1). Isatin also was observed as an abundant peak in both DART(+) and nano-DESI $(+)$ mass spectra, suggesting that it can partition between the gas and particle phases. Smaller peaks produced and then consumed in photooxidation included indoxyl, benzonitrile, and phenylamine. A few peaks at smaller $m / z$ grew during the photooxidation including cyanic acid, acetaldehyde, acetone, and acetic acid.

The particles had a geometric mean diameter of approximately $0.3 \mu \mathrm{m}$ when the filter collection started. The terminal wall-loss-corrected mass concentration of particles (Fig. 3) was higher than the initial concentration of indole, suggesting that the SOA yield, defined by Eq. (1), was high. For five experiments repeated under the same conditions on separate days, the SOA yields calculated from Eq. (1) were 1.21, $1.10,0.86,1.77$, and 1.46 with an average of $1.3 \pm 0.3$. We normally obtain much more reproducible yields for more volatile precursors, such as monoterpenes; it is not clear to the authors why the yield of indole SOA was so variable. Indole oxidation products could be lost to the walls reducing the apparent yield and contributing to its scatter. However,

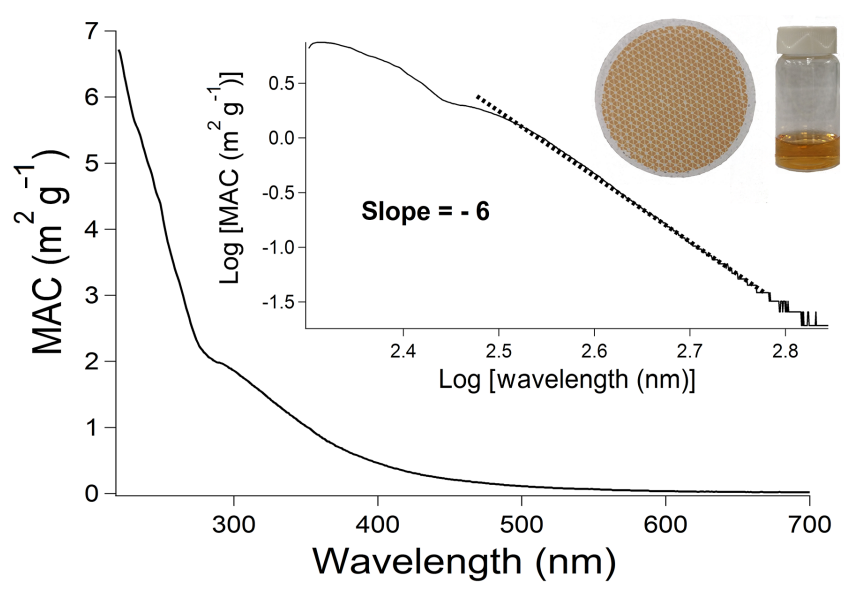

Figure 4. Wavelength-dependent mass absorption coefficient (MAC) of indole SOA. The inset shows the log-log version of the same data used to determine the absorption Angstrom exponent (fitted from 300 to $600 \mathrm{~nm}$ ) and photographs of the indole SOA collected on a filter and extracted in methanol.

this effect is probably minor given that the apparent yield is quite high. The yield is higher than that for SOA formed from another bicyclic aromatic compound, naphthalene, which has a reported yield range of $0.04-0.73$ under low- $\mathrm{NO}_{x}$ conditions (Chan et al., 2009; Chen et al., 2016). The high yield suggests that the major fraction of indole oxidation products ends up in the particle phase at the concentrations used in this work. The yield of 1.3 would require that, on average, at least two oxygen atoms should add to the indole during oxidation $\left(\mathrm{C}_{8} \mathrm{H}_{7} \mathrm{~N} \rightarrow \mathrm{C}_{8} \mathrm{H}_{7} \mathrm{NO}_{2.2}\right)$, which is quite reasonable and qualitatively consistent with mass spectrometric observations.

Figure 4 shows the MAC values measured for an extract of indole SOA in methanol. MAC values reached $\sim 2 \mathrm{~m}^{2} \mathrm{~g}^{-1}$ at $\lambda=300 \mathrm{~nm}$. At $\lambda=400-700 \mathrm{~nm}$, the MAC values ranged from 0.5 to $0.02 \mathrm{~m}^{2} \mathrm{~g}^{-1}$. These high MAC values are comparable to values of strongly absorbing SOA derived from naphthalene or methylpyrroles (Romonosky et al., 2015a) and to MAC values of biomass burning organic aerosol (Sun et al., 2007). The wavelength dependency of MAC deviates from the power law commonly observed for brown carbon (e.g. see reviews of Laskin et al., 2015, and Moise et al., 2015 ) and has a reproducible broad band at $\sim 350 \mathrm{~nm}$, possibly due to the well-known derivatives of indole (indirubin, indigo dye, and indoxyl red) that have characteristic absorption bands at this wavelength (see below). For the wavelength range of 300-600 nm, the absorption Angstrom exponent was $\sim 6$, comparable to the value of $\sim 5$ reported for brown carbon from biomass burning (Kirchstetter et al., 2012).

We used two offline MS methods (DART and nano-DESI) and both negative (-) and positive (+) ion modes to characterize the SOA composition to detect a broader range of compounds than possible with a single method. Figure 5 

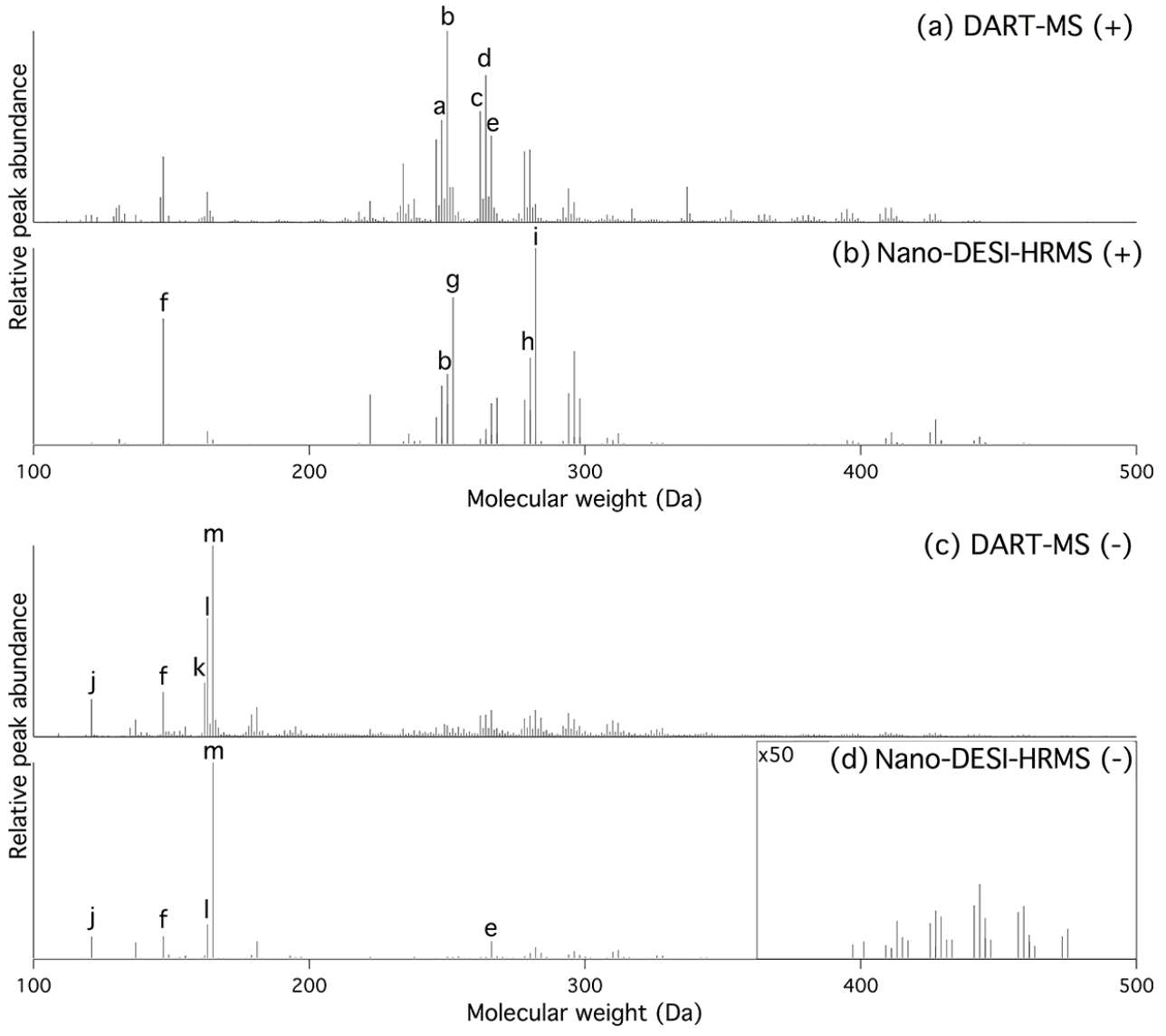

Figure 5. Nano-DESI and DART mass spectra of indole SOA plotted as a function of the molecular weights of the neutral compounds. The nano-DESI mass spectra contain only peaks assignable to specific formulas, while DART mass spectra contain all observed peaks. The five most abundant peaks in each mass spectrum are indicated with letters: (a) $248 \mathrm{Da}, \mathrm{C}_{15} \mathrm{H}_{8} \mathrm{O}_{2} \mathrm{~N}_{2}$; (b) $250 \mathrm{Da}, \mathrm{C}_{15} \mathrm{H}_{10} \mathrm{O}_{2} \mathrm{~N}_{2}$, tryptanthrin; (c) $262 \mathrm{Da}, \mathrm{C}_{16} \mathrm{H}_{10} \mathrm{O}_{2} \mathrm{~N}_{2}$, indirubin and/or indigo dye; (d) $264 \mathrm{Da}, \mathrm{C}_{16} \mathrm{H}_{12} \mathrm{O}_{2} \mathrm{~N}_{2}$, dihydro indigo dye; (e) $266 \mathrm{Da}$, $\mathrm{C}_{15} \mathrm{H}_{10} \mathrm{O}_{3} \mathrm{~N}_{2}$; (f) $147 \mathrm{Da}, \mathrm{C}_{8} \mathrm{H}_{5} \mathrm{O}_{2} \mathrm{~N}$, isatin; (g) $252 \mathrm{Da}, \mathrm{C}_{15} \mathrm{H}_{12} \mathrm{O}_{2} \mathrm{~N}_{2}$; (h) $280 \mathrm{Da}, \mathrm{C}_{16} \mathrm{H}_{12} \mathrm{O}_{3} \mathrm{~N}_{2}$; (i) $282 \mathrm{Da}, \mathrm{C}_{16} \mathrm{H}_{14} \mathrm{O}_{3} \mathrm{~N}_{2}$; (j) $121 \mathrm{Da}, \mathrm{C}_{7} \mathrm{H}_{7} \mathrm{ON}, 2-$ formylformanilide; (k) $162 \mathrm{Da}, \mathrm{C}_{8} \mathrm{H}_{6} \mathrm{O}_{2} \mathrm{~N}_{2}$; (l) $163 \mathrm{Da}, \mathrm{C}_{8} \mathrm{H}_{5} \mathrm{O}_{3} \mathrm{~N}_{2}$, isatoic anhydride; (m) $165 \mathrm{Da}, \mathrm{C}_{8} \mathrm{H}_{7} \mathrm{O}_{3} \mathrm{~N}$.

shows the DART and nano-DESI mass spectra of indole SOA in both positive and negative modes. The high resolving power of nano-DESI-HRMS afforded unambiguous formula assignments for all peaks up to $m / z$ 500, and the molecular weights (MWs) of the neutral compounds could be determined from the corresponding ion formulas. About half of the ions observed in nano-DESI $(+)$ mass spectra were $[\mathrm{M}+$ $\mathrm{Na}^{+}$adducts, and the remaining compounds were protonated ions, $[\mathrm{M}+\mathrm{H}]^{+}$. The DART mass spectra were acquired on a triple quadrupole mass spectrometer with only unity mass resolution. As a result, only the nominal $\mathrm{m} / \mathrm{z}$ values for the observed peaks could be determined. It was assumed that the dominant mechanism of ionization was protonation $\left([\mathrm{M}+\mathrm{H}]^{+}\right.$ions formed; nominal $\mathrm{MW}=$ nominal $\left.m / z-1\right)$ in the positive ion mode and deprotonation $\left([\mathrm{M}-\mathrm{H}]^{-}\right.$ions formed; nominal $\mathrm{MW}=$ nominal $m / z+1$ ) in the negative ion mode (Nah et al., 2013). For ease of comparison, all the mass spectra were plotted as function of the exact mass of the corresponding neutral compounds.
For a given ion mode, the DART and nano-DESI mass spectra were qualitatively similar, although nano-DESI appeared to favour larger, more oxidized compounds compared to DART. Both DART and nano-DESI mass spectra showed a clear separation into distinct clusters of peaks corresponding to monomer, dimer, trimer, and tetramer oxidation products. For a given ion mode, the major monomer peaks were the same in DART and nano-DESI, strongly suggesting that they correspond to more abundant indole oxidation products (as opposed to minor SOA compounds that happened to have unusually high ionization efficiencies). There was also good correspondence between the major dimer peaks recorded in DART and nano-DESI. In the nano-DESI mass spectra, the peak abundances in the negative ion mode spectra were shifted towards higher MWs compared to the positive ion mode mass spectra. The preferential negative ion formation from more oxidized compounds was previously observed in ESI mass spectra of limonene SOA (Walser et al., 2008). Although we cannot assign formulas to the DART-MS peaks, 


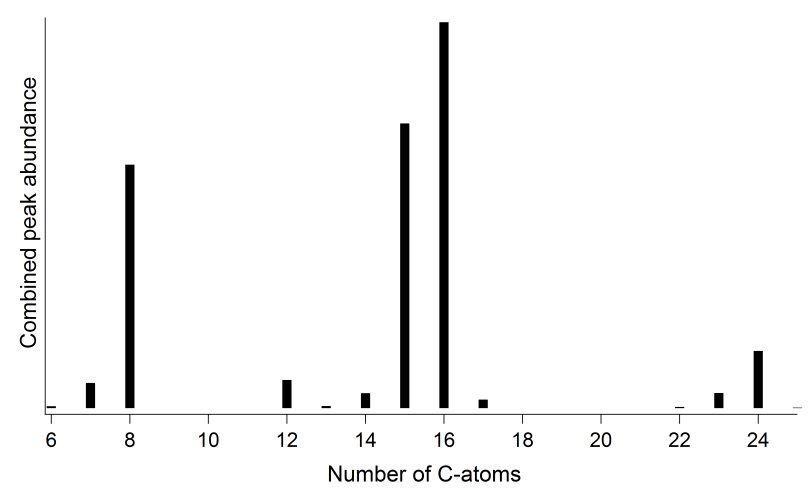

Figure 6. Distribution of the number of $\mathrm{C}$ atoms in the indole SOA compounds detected in both positive and negative ion modes by nano-DESI-HRMS.

it is evident from Fig. 5 that this ionization method also favours larger, and presumably more oxidized, compounds in the negative ion mode. For example, carboxylic acids are more readily observed in the negative ion mode DART mass spectra (Nah et al., 2013).

Table 1 lists the most abundant peaks observed in the monomer and dimer ranges of nano-DESI-HRMS and DART-MS spectra, as well as additional smaller peaks for the specific compounds discussed in this paper. Isatin $\left(\mathrm{C}_{8} \mathrm{H}_{5} \mathrm{O}_{2} \mathrm{~N}, \mathrm{MW}=147 \mathrm{Da}\right)$ was the single dominant peak in the monomer range observed in both nano-DESI $(+)$ and $\operatorname{DART}(+)$; it was also detected in the negative ion mode mass spectra. Isatoic anhydride $\left(\mathrm{C}_{8} \mathrm{H}_{5} \mathrm{O}_{3} \mathrm{~N} ; \mathrm{MW}=163 \mathrm{Da}\right)$ was the second most abundant monomeric peak in all four mass spectra but with much lower abundance. Other abundant monomeric products included 3-oxyindole $\left(\mathrm{C}_{8} \mathrm{H}_{5} \mathrm{ON}\right.$; $\mathrm{MW}=131 \mathrm{Da})$ and 2-formylformanilide $\left(\mathrm{C}_{7} \mathrm{H}_{7} \mathrm{ON}\right.$; $\mathrm{MW}=$ $121 \mathrm{Da})$. Of the compounds shown in Fig. 1, tryptanthrin $\left(\mathrm{C}_{15} \mathrm{H}_{10} \mathrm{O}_{2} \mathrm{~N}_{2} ; \quad \mathrm{MW}=250 \mathrm{Da}\right)$, indirubin $\left(\mathrm{C}_{16} \mathrm{H}_{10} \mathrm{O}_{2} \mathrm{~N}_{2}\right.$; $\mathrm{MW}=262 \mathrm{Da})$, indigo dye $\left(\mathrm{C}_{16} \mathrm{H}_{10} \mathrm{O}_{2} \mathrm{~N}_{2} ; \mathrm{MW}=262 \mathrm{Da}\right)$, and dihydro indigo dye $\left(\mathrm{C}_{16} \mathrm{H}_{12} \mathrm{O}_{2} \mathrm{~N}_{2} ; \mathrm{MW}=264 \mathrm{Da}\right)$ were the most abundant dimer peaks. Meanwhile, indoxyl red $\left(\mathrm{C}_{16} \mathrm{H}_{10} \mathrm{ON}_{2} ; \mathrm{MW}=246 \mathrm{Da}\right)$ was detected with lower but appreciable abundances in nano-DESI(-) and in both DART mass spectra. The prominent dimer compounds listed in Table 1 contained additional oxygen atoms compared to indoxyl red, indirubin, indigo dye, and dihydro indigo dye and could be formed by further oxidation of these compounds.

Figure 6 shows the distribution of the number of $\mathrm{C}$ atoms in the indole SOA compounds, as detected by nano-DESIHRMS (for each group of compounds with the same number of $\mathrm{C}$ atoms, the abundances in the positive and negative ion mode mass spectra were added together). Most of the observed compounds contained 8, 16, or $24 \mathrm{C}$ atoms, corresponding to the monomer, dimer, and trimer derivatives of indole. Peaks with 7 and 15 carbon atoms were also prominent, suggesting an important role of the primary $\mathrm{C}_{7}$ oxidation product 2-formylformanilide in the formation of low volatility species. Minor peaks containing other $\mathrm{C}$ numbers were also present, suggesting further fragmentation of the primary oxidation products. The average formula for all observed SOA compounds was $\mathrm{C}_{15} \mathrm{H}_{11} \mathrm{O}_{3} \mathrm{~N}_{2}$.

Figure $\mathrm{S} 3$ shows the distribution of the $\mathrm{N} / \mathrm{C}$ ratios in indole SOA compounds. Many of the compounds had the same $\mathrm{N} / \mathrm{C}$ ratio as indole $(\mathrm{N} / \mathrm{C}=1 / 8)$, indicating that the oxidation and oligomerization reactions conserved both $\mathrm{N}$ and $\mathrm{C}$ atoms in many of the products. However, some products had a slightly larger ratio consistent with a loss of $\mathrm{C}$ atoms (e.g. $\mathrm{N} / \mathrm{C}=1 / 7$ and $2 / 15$ ), whereas some products gained extra $\mathrm{C}$ atoms. One product with a relatively large abundance, $\mathrm{C}_{12} \mathrm{H}_{14} \mathrm{O}_{4}$, had no $\mathrm{N}$ atoms left in it. In addition, there were several $\mathrm{C}_{8-9} \mathrm{H}_{\mathrm{h}} \mathrm{O}_{0} \mathrm{~N}_{2}$ products that gained an additional $\mathrm{N}$ atom. The mechanism of photooxidation is clearly complex involving a large number of secondary reactions. The full mechanism of indole photooxidation cannot be obtained from this data set. In the discussion that follows, the focus will be on the mechanism of formation of light-absorbing products.

Figure 7 shows the HPLC-PDA chromatogram of an indole SOA sample demonstrating its components with strong light-absorbing properties near-UV and visible spectral ranges (above $300 \mathrm{~nm}$ ). To identify specific chromophores from the HPLC-PDA-HRMS data, the methods described by Lin et al. (2015b, 2016) were followed. High-resolution mass spectra were examined to identify $\mathrm{m} / \mathrm{z}$ values that appear at the retention times associated with the peaks in the HPLC chromatograms. The PDA absorption spectra associated with these retention times were then compared with possible candidates constrained by their molecular formula determined from the mass spectra.

Figure 8 shows a comparison of the absorption spectra for the key peaks in the HPLC-PDA chromatogram with absorption spectra of selected compounds reported in the literature. The match is excellent in terms of the absorption peak maxima: 280, 310, 334, and $392 \mathrm{~nm}$ for tryptanthrin; 240, 283, 335 , and $610 \mathrm{~nm}$ for indigo dye; 242, 290, 365, and $540 \mathrm{~nm}$ for indirubin; and 217, 273, 350, and 520 nm for indoxyl red. The shapes of the spectra do not match perfectly because the chromophores are not fully separated by the HPLC column (Fig. 7) and may co-elute with additional minor compounds. Likely, more than one chromophore contributed to the absorbance at any given retention time. However, the power of the method is clear, as illustrated, for example, by the separation of the structural isomers indigo dye and indirubin (Fig. 7).

The precursors to indoxyl red and indigo dye - dihydro indoxyl red and dihydro indigo dye, respectively - were also identified by this analysis and were observed in nano-DESI mass spectra. This observation supports a mechanism similar to the aqueous-phase indole oxidation proposed by Iddon et al. (1971), in which indole first oxidizes to 3-oxindole, then to dihydro indigo dye or dihydro indoxyl red, and then finally to indigo dye and indoxyl red (Fig. 9a). We note that 


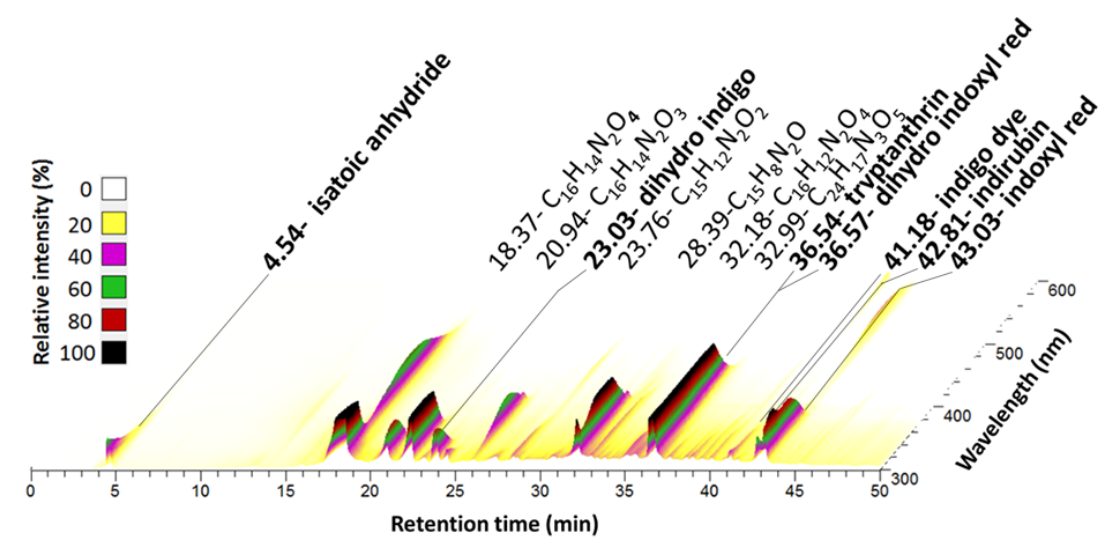

Figure 7. HPLC-PDA chromatogram of indole SOA. The absorbance is plotted as a function of both retention time and wavelength. Peaks are labelled by their PDA retention time followed by their proposed assignment. Bold-faced assignments are specific isomers that are discussed further in the text. Note the reference line for dihydro indigo points to a small peak between two larger peaks that obscure it in this projection.
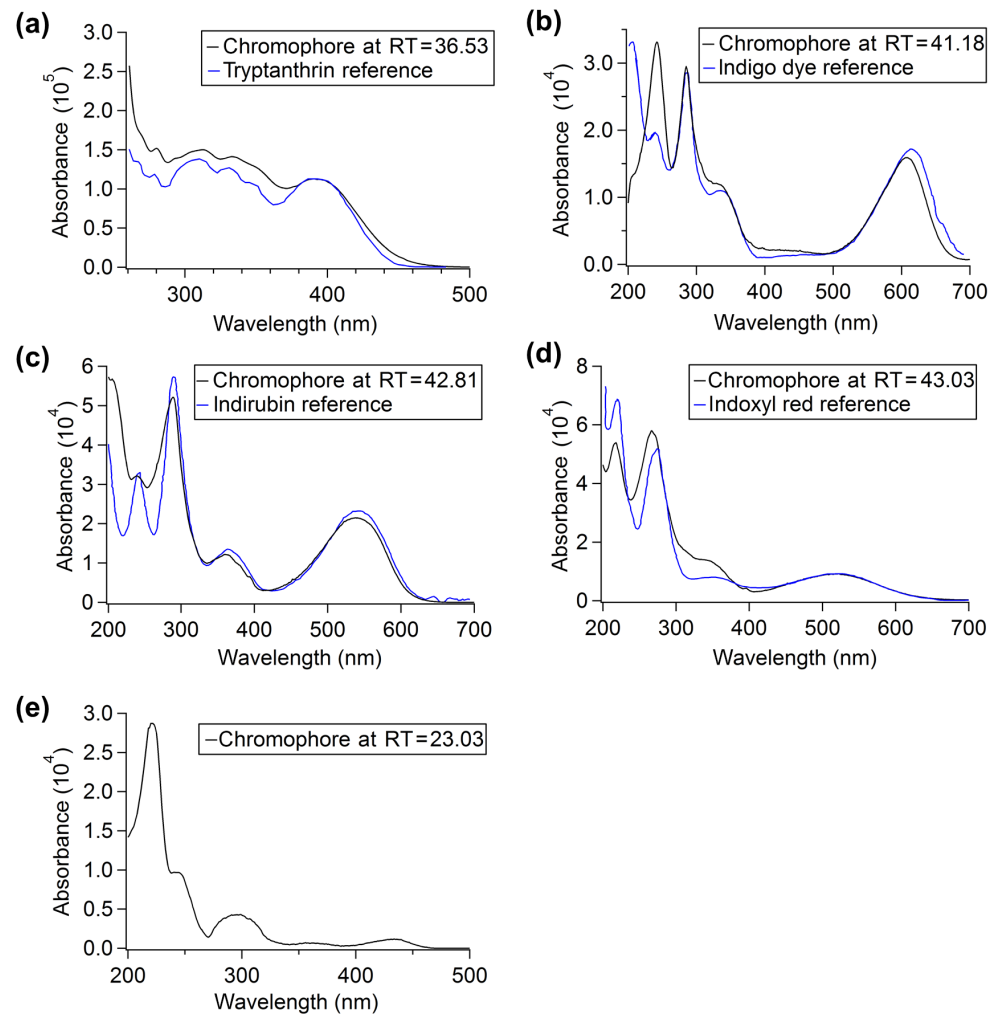

Figure 8. Comparison between measured PDA absorption spectra at selected retention time (RT) and reference spectra of proposed chromophores in the literature (reference spectrum is not available for dihydro indigo dye; panel e).

the mechanism by Iddon et al. (1971) was developed for the aqueous oxidation of indole. While our experiments were performed under dry conditions, it is conceivable that similar oligomerization processes can occur in the gas phase and/or organic particle phase. For example, Healy et al. (2012) observed efficient dimerization of naphthoxy radicals in the gas phase, leading to rapid formation of SOA following photolysis of 1-nitronaphthalene. The dimerization of 3-oxindole to dihydro indigo dye, as well as other oligomerization processes in indole SOA, could follow a mechanism similar to the one described by Healy et al. (2012).

Several products were assigned based on previous observations by Novotna et al. (2003), who studied photodegradation of indigo dye in dichloromethane solution. They proposed the mechanism shown in Fig. $9 \mathrm{~b}$ to explain the production of tryptanthrin and anthranilic acid from ambient indigo 
Table 1. Monomer and dimer peaks with the largest peak abundance observed in DART-MS and nano-DESI-HRMS spectra. Selected peaks corresponding to the compounds shown in Fig. 1 are also included. Proposed assignments are based on the formulas from nano-DESI-HRMS. Peak abundances are normalized with respect to the most abundant peak in each spectrum.

\begin{tabular}{|c|c|c|c|c|c|c|c|c|}
\hline & $\begin{array}{l}\text { Nominal } \\
\text { mass }\end{array}$ & Formula & $\begin{array}{l}\text { Ionization } \\
\text { by } \mathrm{H}^{+} \text {or } \\
\mathrm{Na}^{+} \text {in } \\
\text { nano- } \\
\text { DESI(+) }\end{array}$ & $\begin{array}{c}\text { Peak } \\
\text { abundance } \\
\text { nano-DESI- } \\
\text { HRMS(+) } \\
(\%)\end{array}$ & $\begin{array}{r}\text { Peak } \\
\text { abundance } \\
\text { nano-DESI- } \\
\text { HRMS }(-) \\
(\%)\end{array}$ & $\begin{array}{r}\text { Peak } \\
\text { abundance } \\
\text { DART- } \\
\text { MS(+) } \\
(\%)\end{array}$ & $\begin{array}{r}\text { Peak } \\
\text { abundance } \\
\text { DART- } \\
\text { MS }(-) \\
(\%)\end{array}$ & $\begin{array}{l}\text { Tentative } \\
\text { assignment }\end{array}$ \\
\hline \multirow{11}{*}{$\begin{array}{l}\text { Mono- } \\
\text { mers }\end{array}$} & 121 & $\mathrm{C}_{7} \mathrm{H}_{7} \mathrm{ON}$ & $\mathrm{H}^{+}$ & 0.88 & 11 & 4.0 & 20 & 2-formylformanilide \\
\hline & 130 & - & - & - & - & 7.7 & 0.03 & \\
\hline & 131 & $\mathrm{C}_{8} \mathrm{H}_{5} \mathrm{ON}$ & $\mathrm{H}^{+}$ & 2.7 & - & 9.0 & 0.10 & 3-oxyindole \\
\hline & 133 & $\mathrm{C}_{8} \mathrm{H}_{7} \mathrm{ON}$ & $\mathrm{H}^{+}$ & 0.65 & 0.10 & 4.8 & 0.65 & indoxyl, 3-oxindole \\
\hline & 137 & $\mathrm{C}_{7} \mathrm{H}_{7} \mathrm{O}_{2} \mathrm{~N}$ & - & - & 8.2 & 4.1 & 9.1 & anthranilic acid \\
\hline & 146 & $\mathrm{C}_{8} \mathrm{H}_{6} \mathrm{ON}_{2}$ & $\mathrm{H}^{+}$ & 0.47 & - & 13 & 1.4 & \\
\hline & 147 & $\mathrm{C}_{8} \mathrm{H}_{5} \mathrm{O}_{2} \mathrm{~N}$ & $\mathrm{H}^{+}, \mathrm{Na}^{+}$ & $0.79,64$ & 11 & 34 & 23 & isatin \\
\hline & 162 & $\mathrm{C}_{8} \mathrm{H}_{6} \mathrm{O}_{2} \mathrm{~N}_{2}$ & - & - & 1.8 & 3.2 & 28 & \\
\hline & 163 & $\mathrm{C}_{8} \mathrm{H}_{5} \mathrm{O}_{3} \mathrm{~N}$ & $\mathrm{Na}^{+}$ & 6.7 & 17 & 16 & 62 & isatoic anhydride \\
\hline & 165 & $\mathrm{C}_{8} \mathrm{H}_{7} \mathrm{O}_{3} \mathrm{~N}$ & $\mathrm{Na}^{+}$ & 2.3 & 100 & 3.1 & 100 & \\
\hline & 181 & $\mathrm{C}_{8} \mathrm{H}_{7} \mathrm{O}_{4} \mathrm{~N}$ & - & - & 8.9 & 0.92 & 16 & \\
\hline \multirow[t]{14}{*}{ Dimers } & 246 & $\mathrm{C}_{16} \mathrm{H}_{10} \mathrm{ON}_{2}$ & - & - & 0.37 & 43 & 5.0 & indoxyl red \\
\hline & 248 & $\mathrm{C}_{15} \mathrm{H}_{8} \mathrm{O}_{2} \mathrm{~N}_{2}$ & $\mathrm{H}^{+}, \mathrm{Na}^{+}$ & $3.2,30$ & - & 53 & 1.6 & \\
\hline & 250 & $\mathrm{C}_{15} \mathrm{H}_{10} \mathrm{O}_{2} \mathrm{~N}_{2}$ & $\mathrm{H}^{+}, \mathrm{Na}^{+}$ & 36,21 & 1.0 & 100 & 6.1 & tryptanthrin \\
\hline & 252 & $\mathrm{C}_{15} \mathrm{H}_{12} \mathrm{O}_{2} \mathrm{~N}_{2}$ & $\mathrm{H}^{+}, \mathrm{Na}^{+}$ & $75,0.67$ & 0.72 & 19 & 4.6 & \\
\hline & 262 & $\mathrm{C}_{16} \mathrm{H}_{10} \mathrm{O}_{2} \mathrm{~N}_{2}$ & - & - & 0.88 & 58 & 11 & indirubin, indigo dye \\
\hline & 264 & $\mathrm{C}_{16} \mathrm{H}_{12} \mathrm{O}_{2} \mathrm{~N}_{2}$ & $\mathrm{H}^{+}, \mathrm{Na}^{+}$ & $7.8,2.4$ & 0.36 & 77 & 12 & dihydro indigo dye \\
\hline & 266 & $\mathrm{C}_{15} \mathrm{H}_{10} \mathrm{O}_{3} \mathrm{~N}_{2}$ & $\mathrm{H}^{+}, \mathrm{Na}^{+}$ & $4.9,21$ & 8.9 & 45 & 14 & \\
\hline & 280 & $\mathrm{C}_{16} \mathrm{H}_{12} \mathrm{O}_{3} \mathrm{~N}_{2}$ & $\mathrm{H}^{+}, \mathrm{Na}^{+}$ & 17,44 & 2.8 & 38 & 11 & \\
\hline & 282 & $\mathrm{C}_{15} \mathrm{H}_{10} \mathrm{O}_{4} \mathrm{~N}_{2}$ & $\mathrm{H}^{+}, \mathrm{Na}^{+}$ & $0.26,1.3$ & 5.7 & 9.7 & 14 & \\
\hline & 282 & $\mathrm{C}_{16} \mathrm{H}_{14} \mathrm{O}_{3} \mathrm{~N}_{2}$ & $\mathrm{H}^{+}, \mathrm{Na}^{+}$ & $100,0.29$ & 0.34 & & & \\
\hline & 294 & $\mathrm{C}_{16} \mathrm{H}_{10} \mathrm{O}_{4} \mathrm{~N}_{2}$ & $\mathrm{H}^{+}, \mathrm{Na}^{+}$ & $0.41,26$ & 2.1 & 18 & 12 & \\
\hline & 296 & $\mathrm{C}_{16} \mathrm{H}_{12} \mathrm{O}_{4} \mathrm{~N}_{2}$ & $\mathrm{H}^{+}, \mathrm{Na}^{+}$ & $3.7,48$ & 3.8 & 11 & 9.4 & \\
\hline & 310 & $\mathrm{C}_{16} \mathrm{H}_{10} \mathrm{O}_{5} \mathrm{~N}_{2}$ & $\mathrm{Na}^{+}$ & 2.2 & 3.4 & 3.7 & 8.7 & \\
\hline & 312 & $\mathrm{C}_{16} \mathrm{H}_{12} \mathrm{O}_{5} \mathrm{~N}_{2}$ & $\mathrm{H}^{+}, \mathrm{Na}^{+}$ & $0.18,5.6$ & 4.3 & 2.0 & 7.4 & \\
\hline
\end{tabular}

dye oxidation. In this mechanism, hydroxyl radicals attack the carbonyl carbon atoms of isatin ultimately opening the five-membered $\mathrm{N}$-heterocyclic ring to yield anthranilic acid. Although anthranilic acid does not show up in Fig. 7 because it is not a chromophoric species, it was detected by nanoDESI-HRMS. As shown in Fig. 9b, anthranilic acid can react with another molecule of isatin to produce tryptanthrin. This mechanism is relevant to indole SOA, because isatin can be produced not only from the oxidation of indigo dye but also directly from indole, through the intermediacy of 3-oxindole (Fig. 9a). Moreover, Novotna and colleagues suggested that isatoic anhydride should also be formed from indigo dye oxidation. A compound with this formula had large abundance in both HPLC-PDA-HRMS (Fig. 7) and nano-DESI-HRMS and DART-MS (Fig. 5, Table 1). Combined with the evidence that tryptanthrin is a major secondary chromophore, this could be a significant pathway to brown carbon formation in the oxidation of indole.

We emphasize that the mechanism outlined in Fig. 9 is tentative and is based on the limited information from our experiments and previous experimental data from the literature. Multiple unresolved questions remain. For example, formation of tryptanthrin was very slow in experiments by Novotna et al. (2003), and it is not at clear how this compound could form in just a few hours of photooxidation in the chamber. Furthermore, it is not clear which processes occur in the gaseous phase vs. the particle phase. Although indeterminable from the current experiments, at least some of the dimer formation pathways described in Fig. 9 likely occur in the particle phase.

\subsection{Potential effects of indole SOA}

The spatiotemporal distribution of indole SOA is likely controlled by a combination of (i) the spatiotemporal distribution of gas-phase indole and its emissions sources; (ii) the availability of hydroxyl radical for gas-phase oxidation chemistry; and (iii) meteorological conditions in the region, including temperature, humidity, and wind direction. Once emitted, indole reacts with hydroxyl radical to form gas-phase indigo 
(a)
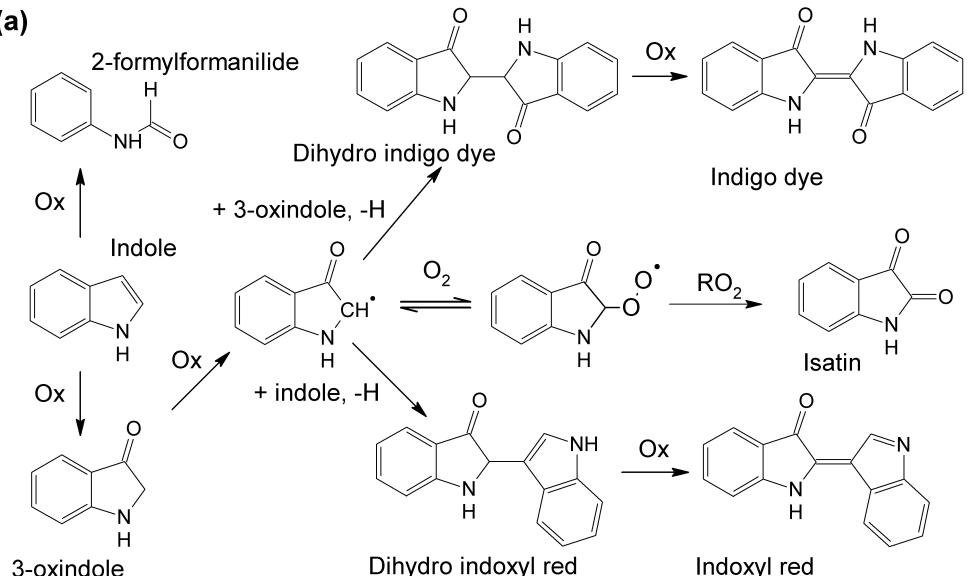

(b)
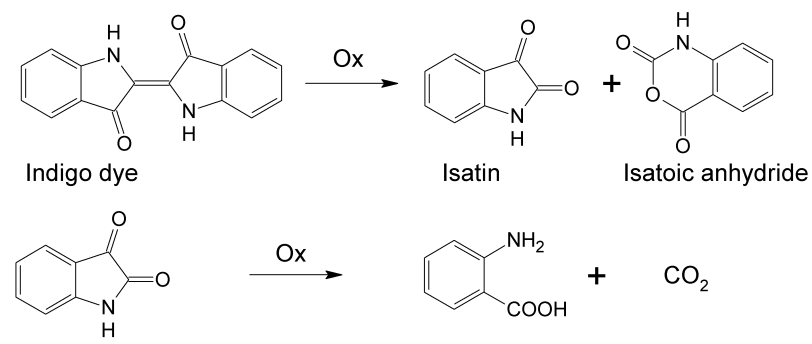

Isatin

Anthranilic acid

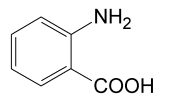

Anthranilic acid

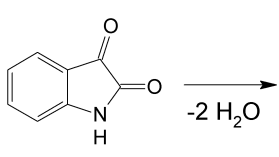

Isatin

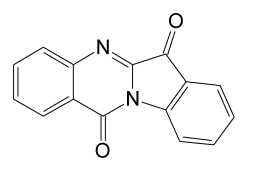

Tryptanthrin

Figure 9. Tentative mechanism for the formation of observed chromophores in the photooxidation of indole. (a) Processes leading to indigo dye and indoxyl red based on Iddon et al. (1971). (b) Processes leading to tryptanthrin based on Novotna et al. (2003). "Ox" denotes an oxidation step.

dye. Gas-phase indigo dye can then partition into the aerosol phase to form indole SOA. The presence of a sea breeze in the SoCAB results in a prevailing wind direction of northnortheast, transporting pollutants inland during the daytime hours. As a result, peak concentrations of indole SOA should be located further inland than peak concentrations of gasphase indole and occur in areas that are already burdened with poor air quality.

Figure S4 shows the spatial distribution of $24 \mathrm{~h}$ average gas-phase indole concentrations in the SoCAB for the low, medium, and high emission scenarios considered in this study. The amount of indole SOA formed in the model, and thus the impact of indole on the total predicted SOA concentrations, depends strongly on the emissions of gas-phase indole. In the high emission scenario, hourly gas-phase indole concentrations peaked at $0.3 \mathrm{ppbv}$, with the highest concentrations occurring in the early morning hours before sunrise (Fig. S5). For comparison, during a field measurement campaign in the San Joaquin Valley of California, Gentner et al. (2014) reported gas-phase indole concentrations of about $1-3$ ppbv in ambient air during a springtime flowering event. Measured concentrations of indole were slightly higher during the late-night and early morning hours than during the daytime, consistent with the model results obtained in this study. Gentner et al. (2014) also showed that flowering was a major biogenic emissions event, causing emissions of many compounds to increase by several factors to over an order of magnitude. Therefore, episodic emissions of indole in rural areas are likely to be significantly greater than the emissions used in this study. Based on the high SOA yield from gas-phase indole found in this study we propose that biogenic emissions events such as springtime flowering may degrade local air quality.

Figure 10a shows $24 \mathrm{~h}$ average SOA concentrations in the base case model simulation, and Fig. 10b-d show the additional SOA resulting from indole in the three emission scenarios. The highest SOA concentrations occurred directly east of Riverside where a combination of biogenic and anthropogenic precursors accumulated during days one and two and into day three. The $24 \mathrm{~h}$ average indole SOA concentra- 

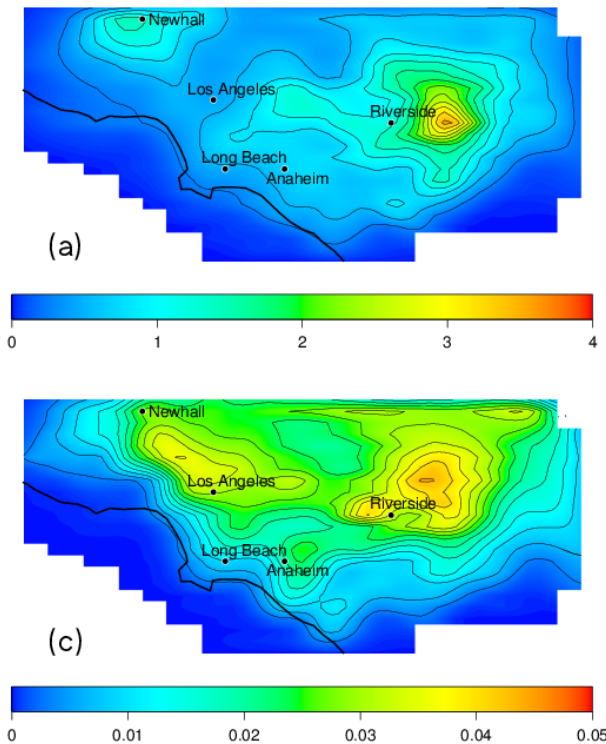
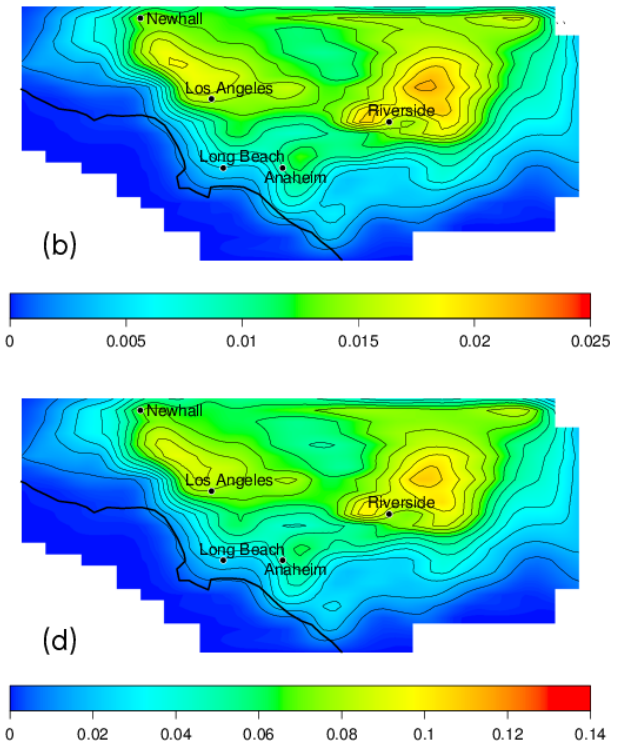

Figure 10. Twenty-four-hour average concentrations $\left(\mu \mathrm{g} \mathrm{m}^{-3}\right)$ of (a) total SOA in the base case and additional SOA resulting from indole photooxidation in (b) the low emission scenario, (c) the medium emission scenario, and (d) the high emission scenario.

tions peaked at about $0.13 \mu \mathrm{g} \mathrm{m}^{-3}$ in the high emission scenario (Fig. 10d). The highest concentrations of indole SOA occurred north of Los Angeles and Riverside. To put this number in perspective, aerosol with mass concentration of $0.1 \mu \mathrm{g} \mathrm{m}^{-3}$ and MAC of $0.5 \mathrm{~m}^{2} \mathrm{~g}^{-1}$ will have an absorption coefficient of $0.05 \mathrm{Mm}^{-1}$ (we neglect the particle size effects in this estimation). Thompson et al. (2012) reported an absorption coefficient of $4 \mathrm{Mm}^{-1}$ at $532 \mathrm{~nm}$ during the 2010 CalNex campaign in Pasadena, California, with the absorption being dominated by black carbon. The average absorption coefficients reported for "average urban USA" and "average remote USA" by Horvath et al. (1993) were 22 and $0.7 \mathrm{Mm}^{-1}$, respectively. While the absorption by indole SOA is unlikely to compete with that by black carbon in urban areas, it may contribute to the aerosol absorption in more remote areas, where the black carbon concentrations are smaller.

SOA concentrations averaged over the entire domain are shown in Fig. 11 for the first four modelled scenarios. The averaged SOA concentrations were computed by averaging the concentration of total SOA in all computational cells in the domain. Therefore, changes in the averaged SOA concentrations are representative of the overall impact on total SOA concentrations for the entire basin. In the high emission scenario, the averaged SOA concentrations increased by about $4-13 \%$, indicating that indole SOA can contribute significantly to total organic aerosol concentrations. While base case SOA concentrations peaked during the early morning and late-night hours when metrological conditions were favourable, the largest changes in SOA concentrations occurred during the late morning and afternoon hours. The formation of gas-phase indigo dye and indole SOA depends on

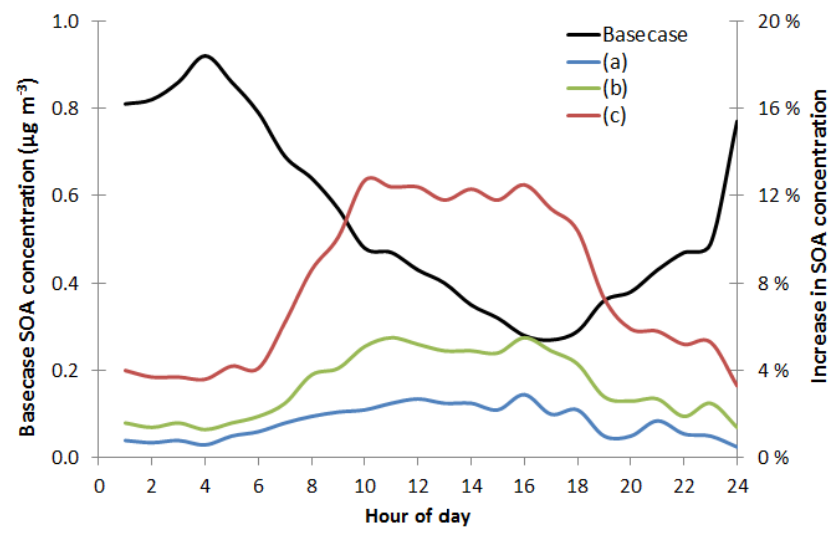

Figure 11. Domain-wide average SOA concentrations in the base case (black line, left axis) and the relative increase in domain-wide average SOA concentrations (right axis) driven by the oxidation of indole by $\mathrm{OH}$ in the (a) low emission scenario, (b) medium emission scenario, and (c) high emission scenario. Figure S6 additionally shows the effect of inclusion of the indole $+\mathrm{NO}_{3}$ reaction on the model.

the availability of the hydroxyl radical, which reaches peak concentrations during daylight hours, when photochemistry is active. Therefore, increased production of hydroxyl radical during the daytime accelerates the oxidation of gas-phase indole, ultimately resulting in increased formation of indole SOA. Increases in total SOA are due mostly to the formation of indole SOA, with only small changes in the concentration of other SOA species.

Figures S5 and S6 suggest that the oxidation of indole via reaction with $\mathrm{NO}_{3}$ may also be an important pathway to in- 
dole SOA formation during the late-night and early morning hours when photochemistry is inactive. When the oxidation of indole via reaction with $\mathrm{NO}_{3}$ is included in the fifth modelled scenario, gas-phase indole concentrations are lower (Fig. S5) and indole SOA concentrations are higher (Fig. S6) than in the fourth scenario. The differences are most pronounced during the late-night and early morning hours due to the different diurnal profiles of $\mathrm{OH}$ and $\mathrm{NO}_{3} ; \mathrm{OH}$ concentrations peak during the daytime hours when photochemistry is active, whereas $\mathrm{NO}_{3}$ concentrations peak at night. Thus, the relative increase in total SOA concentrations due to indole SOA shows less temporal variability throughout the day when the reaction of gas-phase indole with $\mathrm{NO}_{3}$ is included in the model, but peak indole SOA concentrations remain essentially unchanged.

The amount of indole SOA formed in each scenario was found to be directly proportional to the emissions of gasphase indole. In the low emission scenario, gas-phase indole and indole SOA concentrations were about factor of 5 lower than those seen in the high emission scenario, with $24 \mathrm{~h}$ average indole SOA concentrations peaking at about $0.025 \mu \mathrm{g} \mathrm{m}^{-3}$. Similarly, relative increases in the averaged SOA concentrations ranged from 1 to $3 \%$ in the low emission scenario. In the medium emission scenario, $24 \mathrm{~h}$ average indole SOA concentrations reached about $0.05 \mu \mathrm{g} \mathrm{m}^{-3}$, causing total SOA concentrations to increase by $2-6 \%$. In all three emission scenarios, the spatial distribution of indole SOA remained essentially the same, with peak concentrations occurring in the northeast portion of the basin, an area already burdened with poor air quality.

\section{Conclusions}

This work demonstrates that indole is an effective precursor to SOA. At the concentrations used in this chamber study, the majority of indole oxidation products ended up in the particle phase, with an effective SOA yield of $\sim 1.3 \pm 0.3$. The resulting SOA was found to be strongly light absorbing, with MAC values ranging from 0.5 to $0.02 \mathrm{~m}^{2} \mathrm{~g}^{-1}$ across the visible spectrum and approaching those of strongly absorbing brown carbon from biomass burning. The high MAC values were due to well-known chromophoric products of indole oxidation, including tryptanthrin, indirubin, indigo dye, and indoxyl red, which were identified by their molecular formulas and characteristic peaks in their absorption spectra. These observations suggest that $\mathrm{N}$-heterocyclic compounds may be important contributors to secondary brown carbon.

Contribution of indole to SOA formation can potentially result in reduced visibility, particularly in regions where plants are exposed to biotic and abiotic stresses. When combining the experimental MAC values with peak SOA concentrations predicted in the model, the estimated maximum absorption coefficient is $0.05 \mathrm{Mm}^{-1}$ due to indole SOA. This is smaller than the values typically reported for SoCAB but comparable to values reported in more remote areas. Thus, despite its large MAC, indole SOA is not likely to contribute to particle absorption in urban areas, where anthropogenic black carbon dominates the aerosol absorption. However, the situation could be different in remote areas, where black carbon does not contribute to aerosol absorption, and indole emissions are higher.

The UCI-CIT regional airshed model showed significant potential for indole SOA formation driven by the oxidation of indole by $\mathrm{OH}$. Simulations indicate that the oxidation of indole via reaction with $\mathrm{NO}_{3}$ may also be an important SOA formation pathway during the late-night and early morning hours when photochemistry is inactive. While the mass loading of indole SOA in the SoCAB was relatively low in all scenarios, it represents a previously unconsidered source of SOA in air quality models, which have been improved in recent years but still tend to disagree with measured SOA concentrations (Couvidat et al., 2013; Heald et al., 2005; Hodzic et al., 2010; Jiang et al., 2012; Volkamer et al., 2006). Indole SOA can interact with other aerosol-phase species, causing indirect changes in the concentration of total SOA. Such interactions were not considered in this study because an activity coefficient of unity was used for indole SOA in the model simulations. Rural or agricultural regions with significant biomass burning or a high density of plant life likely have much higher emissions of gas-phase indole than the SoCAB. For example, field measurement studies (Gentner et al., 2014) reported ambient indole concentrations up to an order of magnitude greater than the peak modelled concentrations employed in this study, indicating a significant potential for indole SOA formation in rural areas. Furthermore, future climate change is likely to increase gas-phase indole emissions through environmental and physical stress factors such as drought, elevated temperatures, increased $\mathrm{CO}_{2}$ and $\mathrm{O}_{3}$ concentrations, and enhanced herbivore feeding (Yuan et al., 2009). Therefore, indole represents a potentially important source of biogenic SOA that should be included in regional and global models.

Data availability. The raw data from DART-MS, nano-DESIHRMS, HPLC-PDA-HRMS, and PTR-MS instruments are available from the corresponding author upon request.

\section{The Supplement related to this article is available online at https://doi.org/10.5194/acp-17-11605-2017- supplement.}

Competing interests. The authors declare that they have no conflict of interest.

Acknowledgements. This publication was developed under assistance agreement no. EPA 83588101 awarded by the US 
Environmental Protection Agency to the regents of the University of California. It has not been formally reviewed by EPA. The views expressed in this document are solely those of the authors and do not necessarily reflect those of the agency. EPA does not endorse any products or commercial services mentioned in this publication. Julia Montoya-Aguilera acknowledges additional support from the California LSAMP Bridge to the Doctorate Program at the University of California, Irvine, which is funded by grant NSF-1500284. The DART-MS and PTR-ToF-MS instruments used in this work were previously purchased with grants NSF CHE-1337080 and NSF MRI-0923323, respectively. Peng Lin, Julia Laskin, and Alexander Laskin were supported by the US Department of Commerce, National Oceanic and Atmospheric Administration through Climate Program Office's AC4 program, awards NA16OAR4310101 and NA16OAR4310102. The HRMS measurements were performed at the W.R. Wiley Environmental Molecular Sciences Laboratory (EMSL), a national scientific user facility located at PNNL, and sponsored by the Office of Biological and Environmental Research of the US DOE. PNNL is operated for US DOE by Battelle Memorial Institute under contract no. DE-AC06-76RL0 1830.

Edited by: Jason Surratt

Reviewed by: four anonymous referees

\section{References}

Andreae, M. O. and Gelencsér, A.: Black carbon or brown carbon? The nature of light-absorbing carbonaceous aerosols, Atmos. Chem. Phys., 6, 3131-3148, https://doi.org/10.5194/acp-63131-2006, 2006.

Atkinson, R., Tuazon, E. C., Arey, J., and Aschmann, S. M.: Atmospheric and indoor chemistry of gas-phase indole, quinoline, and isoquinoline, Atmos. Environ., 29, 3423-3432, https://doi.org/10.1016/1352-2310(95)00103-6, 1995.

Baluja, S., Bhalodia, R., Bhatt, M., Vekariya, N., and Gajera, R.: Solubitily of a pharmacological intermediate drug isatin in different solvents at various temperatures, Int. Lett. Chem. Phys. Astron., 17, 36-46, https://doi.org/10.18052/www.scipress.com/ILCPA.17.36, 2013

Cardoza, Y. J., Lait, C. G., Schmelz, E. A., Huang, J., and Tumlinson, J. H.: Fungus-induced biochemical changes in peanut plants and their effect on development of beet armyworm, Spodoptera exigua Hübner (Lepidoptera: Noctuidae) larvae, Environ. Entomol., 32, 220-228, https://doi.org/10.1603/0046-225X-32.1.220, 2003.

Carreras-Sospedra, M., Griffin, R. J., and Dabdub, D.: Calculations of incremental secondary organic aerosol reactivity, Environ. Sci. Technol., 39, 1724-1730, https://doi.org/10.1021/es0495359, 2005.

Carreras-Sospedra, M., Dabdub, D., Rodriguez, M., and Brouwer, J.: Air quality modeling in the south coast air basin of California: What do the numbers really mean?, J. Air Waste Manage., 56, 1184-1195, https://doi.org/10.1080/10473289.2006.10464530, 2006.

Carreras-Sospedra, M., Vutukuru, S., Brouwer, J., and Dabdub, D.: Central power generation versus distributed generation-an air quality assessment in the South Coast Air Basin of California, Atmos. Environ., 44, 3215-3223, https://doi.org/10.1016/j.atmosenv.2010.05.017, 2010.

Chan, A. W. H., Kautzman, K. E., Chhabra, P. S., Surratt, J. D., Chan, M. N., Crounse, J. D., Kürten, A., Wennberg, P. O., Flagan, R. C., and Seinfeld, J. H.: Secondary organic aerosol formation from photooxidation of naphthalene and alkylnaphthalenes: implications for oxidation of intermediate volatility organic compounds (IVOCs), Atmos. Chem. Phys., 9, 3049-3060, https://doi.org/10.5194/acp-9-3049-2009, 2009.

Chang, W. L., Griffin, R. J., and Dabdub, D.: Partitioning phase preference for secondary organic aerosol in an urban atmosphere, P. Natl. Acad. Sci. USA, 107, 6705-6710, https://doi.org/10.1073/pnas.0911244107, 2010.

Chen, C., Kacarab, M., Tang, P., and Cocker, D. R.: SOA formation from naphthalene, 1-methylnapthalene, and 2methylnaphthalene photooxidation, Atmos. Environ., 131, 424433, https://doi.org/10.1016/j.atmosenv.2016.02.007, 2016.

Cohan, A., Eiguren-Fernandez, A., Miguel, A. H., and Dabdub, D.: Secondary organic aerosol formation from naphthalene roadway emissions in the South Coast Air Basin of California, Int. J. Environ. Pollut., 52, 206-224, https://doi.org/10.1504/IJEP.2013.058461, 2013.

Couvidat, F., Kim, Y., Sartelet, K., Seigneur, C., Marchand, N., and Sciare, J.: Modeling secondary organic aerosol in an urban area: application to Paris, France, Atmos. Chem. Phys., 13, 983-996, https://doi.org/10.5194/acp-13-983-2013, 2013.

Das, A., Frenkel, M., Gadalla, N. A. M., Kudchadker, S., Marsh, K. N., Rodgers, A. S., and Wilhoit, R. C.: Thermodynamic and thermophysical properties of organic nitrogen compounds: Part II. 1- and 2-butanamine, 2-methyl1-propanamine, 2-methyl-2-propanamine, pyrrole, 1-, 2-, 3methylpyrrole, pyridine, 2-, 3-, and 4-methylpyridine, pyrrolidine, piperidine, indole, quinolone, isoquinoline, acridine, carbazole, phenanthridine, 1- and 2-naphthalenamine, and 9methylcarbazole, J. Phys. Chem. Ref. Data, 22, 659-782, https://doi.org/10.1063/1.555925, 1993.

Dawson, M. L., Xu, J., Griffin, R. J., and Dabdub, D.: Development of aroCACM/MPMPO 1.0: a model to simulate secondary organic aerosol from aromatic precursors in regional models, Geosci. Model Dev., 9, 2143-2151, https://doi.org/10.5194/gmd9-2143-2016, 2016.

De Boer, J. G., Posthumus, M. A., and Dicke, M.: Identification of volatiles that are used in discrimination between plants infested with prey or nonprey herbivores by a predatory mite, J. Chem. Ecol., 30, 2215-2230, https://doi.org/10.1023/B:JOEC.0000048784.79031.5e, 2004.

Erb, M., Veyrat, N., Robert, C. A. M., Xu, H., Frey, M., Ton, J., and Turlings, T. C. J.: Indole is an essential herbivore-induced volatile primal signal in maize, Nature Communications, 6, 6273, https://doi.org/10.1038/ncomms7273, 2015.

Feilberg, A., Liu, D., Adamsen, A. P. S., Hansen, M. J., and Jonassen, K. E. N.: Odorant emissions from intensive pig production measured by online proton-transfer-reaction mass spectrometry, Environ. Sci. Technol., 44, 5894-5900, https://doi.org/10.1021/es100483s, 2010.

Frey, M., Spiteller, D., Boland, W., and Gierl, A.: Transcriptional activation of Igl, the gene for indole formation in Zea mays: a structure-activity study with elicitor-active $\mathrm{N}$ - 
acyl glutamines from insects, Phytochemistry, 65, 1047-1055, https://doi.org/10.1016/j.phytochem.2003.11.021, 2004.

Gentner, D. R., Ormeño, E., Fares, S., Ford, T. B., Weber, R., Park, J.-H., Brioude, J., Angevine, W. M., Karlik, J. F., and Goldstein, A. H.: Emissions of terpenoids, benzenoids, and other biogenic gas-phase organic compounds from agricultural crops and their potential implications for air quality, Atmos. Chem. Phys., 14, 5393-5413, https://doi.org/10.5194/acp-14-5393-2014, 2014.

Gols, R., Posthumus, M. A., and Dicke, M.: Jasmonic acid induces the production of gerbera volatiles that attract the biological control agent Phytoseiulus persimilis, Entomol. Exp. Appl., 93, 7786, https://doi.org/10.1046/j.1570-7458.1999.00564.x, 1999.

Griffin, R. J., Dabdub, D., and Seinfeld, J. H.: Secondary organic aerosol 1. Atmospheric chemical mechanism for production of molecular constituents, J. Geophys. Res., 107, 4332, https://doi.org/10.1029/2001JD000541, 2002a.

Griffin, R. J., Dabdub, D., Kleeman, M. J., Fraser, M. P., Cass, G. R., and Seinfeld, J. H.: Secondary organic aerosol 3. Urban/regional scale model of size- and composition- resolved aerosols, J. Geophys. Res., 107, 4334, https://doi.org/10.1029/2001JD000544, 2002b.

Griffin, R. J., Nguyen, K., Dabdub, D., and Seinfeld, J. H.: A coupled hydrophobic-hydrophilic model for predicting secondary organic aerosol formation, J. Atmos. Chem., 44, 171190, https://doi.org/10.1023/A:1022436813699, 2003.

Griffin, R. J., Dabdub, D., and Seinfeld, J. H.: Development and initial evaluation of a dynamic species-resolved model for gas phase chemistry and size-resolved gas/particle partitioning associated with secondary organic aerosol formation, J. Geophys. Res., 110, D05304, https://doi.org/10.1029/2004JD005219, 2005.

Hansen, H. K., Rasmussen, P., Fredenslund, A., Schiller, M., and Gmehling, J.: Vapor-liquid equilibria by UNIFAC group contribution. 5. Revision and extension, Ind. Eng. Chem. Res., 30, 2352-2355, https://doi.org/10.1021/ie00058a017, 1991.

Heald, C. L., Jacob, D. J., Park, R. J., Russell, L. M., Huebert, B. J., Seinfeld, J. H., Liao, H., and Weber, R. J.: A large organic aerosol source in the free troposphere missing from current models, Geophys. Res. Lett., 32, L18809, https://doi.org/10.1029/2005GL023831, 2005.

Healy, R. M., Chen, Y., Kourtchev, I., Kalberer, M., O'Shea, D., and Wenger, J. C.: Rapid formation of secondary organic aerosol from the photolysis of 1-nitronaphthalene: role of naphthoxy radical self-reaction, Environ. Sci. Technol., 46, 11813-11820, https://doi.org/10.1021/es302841j, 2012.

Hobbs, P., Webb, J., Mottram, T., Grant, B., and Misselbrook, T.: Emissions of volatile organic compounds originating from UK livestock agriculture, J. Sci. Food Agr., 84, 1414-1420, https://doi.org/10.1002/jsfa.1810, 2004.

Hodzic, A., Jimenez, J. L., Madronich, S., Canagaratna, M. R., DeCarlo, P. F., Kleinman, L., and Fast, J.: Modeling organic aerosols in a megacity: potential contribution of semi-volatile and intermediate volatility primary organic compounds to secondary organic aerosol formation, Atmos. Chem. Phys., 10, 5491-5514, https://doi.org/10.5194/acp-10-5491-2010, 2010.

Horvath, H.: Atmospheric light-absorption - a review, Atmos. Environ., 27, 293-317, https://doi.org/10.1016/0960-1686(93)901047, 1993.

Iddon, B., Phillips, G. O., Robbins, K. E., and Davies, J. V.: Radiation chemistry of aqueous solutions of indole and its derivatives, J. Chem. Soc. B., 1887-1892, https://doi.org/10.1039/J29710001887, 1971.

Jiang, F., Liu, Q., Huang, X., Wang, T., Zhuang, B., and Xie, M.: Regional modeling of secondary organic aerosol over China using WRF/Chem, J. Aerosol Sci., 43, 57-73, https://doi.org/10.1016/j.jaerosci.2011.09.003, 2012.

Kirchstetter, T. W. and Thatcher, T. L.: Contribution of organic carbon to wood smoke particulate matter absorption of solar radiation, Atmos. Chem. Phys., 12, 6067-6072, https://doi.org/10.5194/acp-12-6067-2012, 2012.

Laskin, A., Laskin, J., and Nizkorodov, S. A.: Chemistry of atmospheric brown carbon, Chem. Rev., 115, 4335-4382, https://doi.org/10.1021/cr5006167, 2015.

Laskin, A., Smith, J. S., and Laskin, J.: Molecular characterization of nitrogen-containing organic compounds in biomass burning aerosols using high-resolution mass spectrometry, Environ. Sci. Technol., 43, 3764-3771, https://doi.org/10.1021/es803456n, 2009.

Lin, P., Laskin, J., Nizkorodov, S. A., and Laskin, A.: Revealing brown carbon chromophores produced in reaction of methylglyoxal with ammonium sulfate, Environ. Sci. Technol., 49, 1425714266, https://doi.org/10.1021/acs.est.5b03608, 2015a.

Lin, P., Liu, J., Shilling, J. E., Kathmann, S. M., Laskin, J., and Laskin, A.: Molecular characterization of brown carbon $(\mathrm{BrC})$ chromophores in secondary organic aerosol generated from photo-oxidation of toluene, Phys. Chem. Chem. Phys., 17, 23312, https://doi.org/10.1039/C5CP02563J, 2015b.

Lin, P., Aiona, P. K., Li, Y., Shiraiwa, M., Laskin, J., Nizkorodov, S. A., and Laskin, A.: Molecular characterization of brown carbon in biomass burning aerosol particles, Environ. Sci. Technol., 50, 11815-11824, https://doi.org/10.1021/acs.est.6b03024, 2016.

Liu, J. Q., Chen, S. Y., and Ji, B.: Solubility and thermodynamic functions of isatin in pure solvents, J. Chem. Eng. Data, 59, 3407-3414, https://doi.org/10.1021/je500396b, 2014.

McCall, P. J., Turlings, T. C., Lewis, W. J., and Tumlinson, J. H.: Role of plant volatiles in host location by the specialist parasitoidMicroplitis croceipes Cresson (Braconidae: Hymenoptera), J. Insect Behav., 6, 625-639, https://doi.org/10.1007/BF01048128, 1993.

Misztal, P. K., Hewitt, C. N., Wildt, J., Blande, J. D., Eller, A. S. D., Fares, S., Gentner, D. R., Gilman, J. B., Graus, M., Greenberg, J., Guenther, A. B., Hansel, A., Harley, P., Huang, M., Jardine, K., Karl, T., Kaser, L., Keutsch, F. N., Kiendler-Scharr, A., Kleist, E., Lerner, B. M., Li, T., Mak, J., Nolscher, A. C., Schnitzhofer, R., Sinha, V., Thornton, B., Warneke, C., Wegener, F., Werner, C., Williams, J., Worton, D. R., Yassaa, N., and Goldstein, A. H.: Atmospheric benzenoid emissions from plants rival those from fossil fuels, Sci. Rep.-UK, 5, 12064 , https://doi.org/10.1038/srep12064, 2015.

Moise, T., Flores, J.M, and Rudich, Y.: Optical properties of secondary organic aerosols and their changes by chemical processes, Chem. Rev., 115, 4400-4439, https://doi.org/10.1021/cr5005259, 2015.

Nah, T., Chan, M., Leone, S. R., and Wilson, K. R.: Real time in situ chemical characterization of submicrometer organic particles using direct analysis in real time-mass spectrometry, Anal. Chem., 85, 2087-2095, https://doi.org/10.1021/ac302560c, 2013. 
Nguyen, K. and Dabdub, D.: $\mathrm{NO}_{x}$ and VOC control and its effects on the formation of aerosols, Aerosol Sci. Tech., 36, 560-572, https://doi.org/10.1080/02786820252883801, 2002.

Niinemets, U., Kannaste, A., and Copolovici, L.: Quantitative patterns between plant volatile emissions induced by biotic stresses and the degree of damage, Front. Plant. Sci., 4, 1-15, https://doi.org/10.3389/fpls.2013.00262, 2013.

Novotna, P., Boon, J. J., Horst, J., and Pacakova, V.: Photodegradation of indigo in dichloromethane solution, Color. Technol., 119, 121-127, https://doi.org/10.1111/j.1478-4408.2003.tb00161.x, 2003.

Pankow, J. F. and Asher, W. E.: SIMPOL.1: a simple group contribution method for predicting vapor pressures and enthalpies of vaporization of multifunctional organic compounds, Atmos. Chem. Phys., 8, 2773-2796, https://doi.org/10.5194/acp-8-27732008, 2008.

Price, D. J., Clark, C. H., Tang, X. C., Cocker, D. R., PurvisRoberts, K. L., and Silva, P. J.: Proposed chemical mechanisms leading to secondary organic aerosol in the reactions of aliphatic amines with hydroxyl and nitrate radicals, Atmos. Environ., 96, 135-144, https://doi.org/10.1016/j.atmosenv.2014.07.035, 2014.

Romonosky, D. E., Ali, N. N., Saiduddin, M. N., Wu, M., Lee, H. J., Aiona, P. K., and Nizkorodov, S. A.: Effective absorption cross sections and photolysis rates of anthropogenic and biogenic secondary organic aerosols, Atmos. Environ., 130, 172-179, https://doi.org/10.1016/j.atmosenv.2015.10.019, 2015a.

Romonosky, D. E.; Laskin, A.; Laskin, J.; and Nizkorodov, S. A.: High-resolution mass spectrometry and molecular characterization of aqueous photochemistry products of common types of secondary organic aerosols, J. Phys. Chem. A, 119, 2594-2606, https://doi.org/10.1021/jp509476r, 2015b.

SCAQMD: Final 2012 Air Quality Management Plan, Tech. rep., South Coast Air Quality Management District, Diamond Bar, California, available at: http://www.aqmd. gov/home/library/clean-air-plans/air-quality-mgt-plan/ final-2012-air-quality-management-plan, last access: 15 January 2015 .

Schmelz, E. A., Alborn, H. T., Banchio, E., and Tumlinson, J. H.: Quantitative relationships between induced jasmonic acid levels and volatile emission in Zea mays during Spodoptera exigua herbivory, Planta, 216, 665-673, 2003.

Silva, P. J., Erupe, M. E., Price, D., Elias, J., Malloy, Q. G. J., Li, Q., Warren, B., and Cocker, D. R. III: Trimethylamine as precursor to secondary organic aerosol formation via nitrate radical reaction in the atmosphere, Environ. Sci. Technol., 42, 4689-4696, https://doi.org/10.1021/es703016v, 2008.

Sun, H., Biedermann, L., and Bond, T. C.: Color of brown carbon: a model for ultraviolet and visible light absorption by organic carbon aerosol, Geophys. Res. Lett., 34, L17813, https://doi.org/10.1029/2007GL029797, 2007.

Suzuki, T., Ohtaguchi, K., and Koide, K.: Application of principal components analysis to calculate Henry's constant from molecular structure, Comput. Chem., 16, 41-52, https://doi.org/10.1016/0097-8485(92)85007-L, 1992.

Thompson, J. E., Hayes, P. L., Jimenez, J. L., Adachi, K., Zhang, X., Liu, J., Weber, R. J., and Buseck, P. R.: Aerosol optical properties at Pasadena, CA during CalNex 2010, Atmos. Environ., 55, 190200, https://doi.org/10.1016/j.atmosenv.2012.03.011, 2012.
Turlings, T. C., Tumlinson, J. H., and Lewis, W. J.: Exploitation of herbivore-induced plant odors by host-seeking parasitic wasps, Science, 250, 1251-1253, 1990.

Turlings, T. C. and Wäckers, F.: Recruitment of predators and parasitoids by herbivore-injured plants, in: Advances in Insect Chemical Ecology, Cambridge University Press, Cambridge, 21-75, 2004.

Volkamer, R., Jimenez, J. L., San Martini, F., Dzepina, K., Zhang, Q., Salcedo, D., Molina, L. T., Worsnop, D. R., and Molina, M. J.: Secondary organic aerosol formation from anthropogenic air pollution: rapid and higher than expected, Geophys. Res. Lett., 33, L17811, https://doi.org/10.1029/2006GL026899, 2006.

Vutukuru, S., Griffin, R. J., and Dabdub, D.: Simulation and analysis of secondary organic aerosol dynamics in the South Coast Air Basin of California, J. Geophys. Res., 111, D10S12, https://doi.org/10.1029/2005JD006139, 2006.

Walser, M. L., Desyaterik, Y., Laskin, J., Laskin, A., and Nizkorodov, S. A.: High-resolution mass spectrometric analysis of secondary organic aerosol produced by ozonation of limonene, Phys. Chem. Chem. Phys., 10, 1009-1022, https://doi.org/10.1039/B712620D, 2008.

Wright, D. W., Eaton, D. K., Nielsen, L. T., Kuhrt, F. W. Koziel, J. A., Spinhirne, J. P., and Parker, D. B.: Multidimensional gas chromatography - olfactometry for the identification and prioritization of malodors from confined animal feeding operations, J. Agr. Food Chem., 53, 8663-8672, https://doi.org/10.1021/jf050763b, 2005.

Yuan, B., Coggon, M. M., Koss, A. R., Warneke, C., Eilerman, S., Peischl, J., Aikin, K. C., Ryerson, T. B., and de Gouw, J. A.: Emissions of volatile organic compounds (VOCs) from concentrated animal feeding operations (CAFOs): chemical compositions and separation of sources, Atmos. Chem. Phys., 17, 49454956, https://doi.org/10.5194/acp-17-4945-2017, 2017.

Yuan, J. S., Himanen, S. J., Holopainen, J. K., Chen, F., and Stewart, C. N.: Smelling global climate change: mitigation of function for plant volatile organic compounds, Trends Ecol. Evol., 24, 323-331, https://doi.org/10.1016/j.tree.2009.01.012, 2009.

Zhuang, X., Fiesselmann, A., Zhao, N., Chen, H., Frey, M., and Chen, F.: Biosynthesis and emission of insect herbivoryinduced volatile indole in rice, Phytochemistry, 73, 15-22, https://doi.org/10.1016/j.phytochem.2011.08.029, 2012.

Zito, P., Doetterl, S. Sajeva, M.: Floral volatiles in a sapromyiophilous plant and their importance in attracting house fly pollinators, J. Chem. Ecol., 41, 340-349, https://doi.org/10.1007/s10886-015-0568-8, 2015. 